\title{
SZTUCZNA INTELIGENCJA (AI), INTERNET RZECZY (IOT) I SIEĆ PIĄTEJ GENERACJI (5G) W NOWOCZESNYCH BADANIACH NAUKOWYCH
}

\begin{abstract}
Zdzisław W. Puślecki, Sztuczna inteligencja (Al), internet rzeczy (IoT) i sieć piq̨tej generacji (5G) w nowoczesnych badaniach naukowych [Artificial intelligence (Al), the Internet of things (loT), and the fifth generation (5G) network in the modern science research] edited by Zbigniew Drozdowicz, Sławomir Sztajer ", Człowiek i Społeczeństwo" vol. Lll: Globalne i lokalne problemy życia akademickiego [Global and local problems of academic life], Poznań 2021, pp. 123-164, Adam Mickiewicz University. ISSN 0239-3271, https://doi.org/10.14746/cis.2021.52.7.
\end{abstract}

In the coming time, the innovative success of customer service will depend on having a data- driven strategy. Automation will play a key role in employee service initiatives. The progress and implementation of robot-based process automation, as well as machine learning, artificial intelligence (Al), the Internet of things (IoT), and the construction of the fifth generation $5 \mathrm{G}$ network will be important. Trends such as gamification, Big Data and Al are visible. Thanks to this, the right vision is created, supported by the necessary technical knowledge, to implement solutions that open the gate of undiscovered business potential. Modern technology is also becoming a tool of public surveillance. The aim of the study is to present artificial intelligence and the Internet of things as well as the construction of the fifth generation - $5 \mathrm{G}$ networks in the face of innovative challenges resulting from the economic crisis caused by the COVID-19 pandemic.

Keywords: innovation, modern science research, artificial intelligence, Internet of things, fifth generation - $5 \mathrm{G}$ network

Zdzisław W. Puślecki, Uniwersytet im. Adama Mickiewicza w Poznaniu, Wydział Nauk Politycznych i Dziennikarstwa, ul. Uniwersytetu Poznańskiego 5, 61-614 Poznań, e-mail: zdzislaw.puslecki@amu. edu.pl, https://orcid.org/0000-0003-1838-9993. 


\section{Wprowadzenie}

Sztuczna inteligencja (Artificial Intelligence - AI), internet rzeczy (Internet of Things - IoT), budowa sieci piątej generacji (5G) stają się fundamentami systemów IT i stopniowo będą przejmować na siebie wiele procesów decyzyjnych, co nie jest bez znaczenia w nowoczesnych badaniach naukowych. Powszechnie łączy się zamiłowanie do nowoczesnych technologii z wieloletnim doświadczeniem zdobytym w analizach dużych zbiorów danych oraz tworzeniu aplikacji analitycznych. Powstają interdyscyplinarne zespoły specjalizujące się w wykorzystaniu narzędzi sztucznej inteligencji oraz uczenia maszynowego (Machine Learning), a w szczególności modeli klasyfikacyjnych, predykcyjnych oraz klastrowania danych.

Widoczne są takie trendy, jak gamifikacja, Big Data oraz AI. Dzięki temu powstaje właściwa wizja poparta niezbędną wiedzą techniczną, aby wdrażać rozwiązania, które otwierają bramę nieodkrytego potencjału biznesowego. Celem opracowania jest przedstawienie sztucznej inteligencji, internetu rzeczy, budowy sieci piątej generacji (5G) oraz sposobów wykorzystywania nowoczesnych technologii w warunkach COVID-19.

\section{Badania naukowe, sztuczna inteligencja i internet rzeczy}

W rezultacie procesów rozwojowych nieustannie wzrasta rola edukacji. Jednym z najciekawszych współczesnych zjawisk jest umiędzynarodowienie badań i prac rozwojowych. Ponad wszystko właśnie badania i prace rozwojowe są czystą informacją. Mogą one opierać się na fizycznych eksperymentach w tym lub innym miejscu, ale ich przekaz, wymiana i planowanie są w dużym stopniu czystą informacją. Wcześniej nauka była globalnym przedsięwzięciem wymagającym komunikacji między naukowcami przez wydawnictwa czy konferencje. Dzięki możliwościom taniej telekomunikacji korporacje posiadają własne ośrodki badawcze na całym świecie i koordynują ich działalność. Korporacje ze swymi nowymi sieciami mogą wybierać i zatrudniać najlepszych i najinteligentniejszych pracowników w wysoce konkurencyjnej światowej sytuacji, ponieważ oferują zatrudnionym najlepsze płace, możliwości i zaplecze. Ważną rolę w tym względzie, szczególnie w krajach słabiej rozwiniętych, odgrywają procesy edukacji 
na poziomie wyższym, w tym również nowe formy nauki i kształcenia, takie jak samokształcenie czy kształcenie na odległość.

Podniesienie komercjalizacji badań naukowych wymaga zwiększenia aktywności środowiska naukowego w kierunku podniesienia atrakcyjności komercjalizacji wynalazku i zwiększenia zainteresowania przedsiębiorców krajowymi innowacjami, tak aby zastosowanie polskich rozwiązań było bardziej atrakcyjne niż zakupienie technologii za granicą. Inwestorzy, czyli rynek finansowy, powinni skupić się natomiast nie tylko na fin-techach, lecz także na technologiach przemysłowych, ponieważ mogą one przynieść poważne zyski. Rozwiązanie tego problemu wymaga nowej polityki przemysłowej i naukowej. W istocie należy zdynamizować relacje głównych graczy: uczonych, przedsiębiorców i inwestorów. Jednocześnie potrzebne są nowoczesne środki edukacyjne, finansowe i prawne.

Nauka jest skomplikowanym ekosystemem, w którym nie można uzyskać przełomowych, oryginalnych rozwiązań praktycznych bez wysokiej klasy, kreatywnych badań podstawowych. Z kolei impuls do poszukiwań nowych odpowiedzi w zakresie badań podstawowych często nadchodzi z obszaru zastosowań wiedzy, w którym następuje zderzenie z brakiem satysfakcjonujących rozwiązań dla podejmowanych problemów. Stworzenie warunków stymulujących wysokiej klasy badania podstawowe i stosowane jest jednym z głównych celów reformy nauki i szkolnictwa wyższego.

Wzrost konkurencyjności przedsiębiorstw zależy przede wszystkim od wprowadzania przez nie innowacji, zwłaszcza nowych w skali branży. Większe szanse na wprowadzenie takich innowacji mają zaś te firmy, które intensywniej współpracują z pozostałymi podmiotami systemu innowacyjnego, a głównie z uczelniami technicznymi. Należy przy tym zaznaczyć, że firmy współpracujące z innymi przedsiębiorstwami w pracach badawczo-rozwojowych $(\mathrm{B}+\mathrm{R})$ mają wyższe średnie przychody z innowacji. Ponadto drobne firmy współpracujące w procesie innowacyjnym lepiej postrzegają swoją pozycję konkurencyjną w zakresie opóźnienia technologicznego w stosunku do konkurentów.

Ważność związków nauki, przemysłu i zarządzania wymusza zmieniający się charakter technologii, która jest złożona i systemowa. Prowadzi to do kreacji wiedzy w przedsiębiorstwach, która jest nie tylko specyficzna, lecz także zależy od rozwoju komplementarnych, a czasem podstawowych dziedzin nauki. Istnieje zatem pozytywna zależność między interaktywnym sposobem prowadzenia działalności innowacyjnej a efektywnością procesu innowacyjnego. Oznacza to, że założenia koncepcji systemu innowacyjnego są słuszne, a intensyfikacja powiązań między podmiotami tego systemu 
może sprzyjać innowacyjności i konkurencyjności przedsiębiorstw. Badania nad innowacyjnością dowiodły, że znacznie więcej interakcji i współpracy zachodzi między elementami systemu innowacyjnego na poziomie regionu niż państwa.

W procesach rozwojowych obserwuje się nową dynamikę, która wpływa na kreowanie społeczeństwa informacyjnego. Olbrzymią rolę w tej dynamice odgrywają rozwój technologiczny oraz innowacyjność. Dzięki rewolucji technologicznej koszty przesyłania i pozyskiwania informacji zostały znacząco obniżone, a dyfuzja innowacji uległa przyspieszeniu. Firmy wykorzystują model online lub offline, a najczęściej połączenie obu, co nazwano bricks and clicks. Małe i średnie firmy mogą więc inwestować na początek w środki trwałe, ale dla zaoszczędzenia kosztów powinny stosować rozwiązania online, np. zawieranie umowy drogą elektroniczną (online) i fizyczne dostarczenie towaru/usługi (offline). Należy podkreślić, że dla firm pojawiają się głównie konkurenci zagraniczni.

W wielu przemysłach (zwanych Przemysłami 4.0) nowa gospodarka (nazywana Gospodarką 4.0) powoduje modularyzację działalności innowacyjnej. Warto również zaznaczyć, że Przemysł 4.0 pojawił się w następstwie szybkiego rozwoju technologii informatycznych i robotyki, które wspólnie doprowadziły do skonstruowania nowych rodzajów zintegrowanych systemów produkcyjnych i nowej organizacji produkcji. Gospodarka 4.0 obejmuje zatem nie tylko Przemysł 4.0, lecz także inteligentne środowiska pracy i życia, opierające się na sztucznej inteligencji i wykraczające poza sam przemysł.

Współczesna informatyka bardziej niż kiedykolwiek jest skupiona na obiegu danych. Dane są masowo zbierane przez internet osób i internet rzeczy. Internet osób jest doskonale znany - komunikatory, e-maile, media społecznościowe, wyszukiwarki, e-zakupy, e-bankowość, e-dydaktyka, gry, filmy. Uważa się, że tylko 15\% handlu elektronicznego to handel na linii przedsiębiorstwo-klient, który jest widoczny w Internecie, tymczasem 85\% obejmuje handel przedsiębiorstwo-przedsiębiorstwo, ukryty przed internautami, widoczny jedynie dla partnerów biznesowych. Internet rzeczy natomiast jest koncepcją stosunkowo nową. Jest to system rozproszonych, wzajemnie powiązanych cyfrowych identyfikatorów, komunikatorów, sensorów i aktuatorów wbudowanych w rzeczy lub noszonych przez osoby i zwierzęta, mogących się identyfikować i przesyłać dane przez sieć telekomunikacyjną bez potrzeby interakcji człowiek-człowiek lub człowiek-komputer. Dzięki temu społeczeństwo funkcjonuje w otoczeniu tzw. inteligentnych rzeczy, komunikujących się między sobą w celu zapewnienia 
społeczeństwu komfortu i bezpieczeństwa. W przyszłości będzie to mieć różne zastosowania i znaczenie dla różnych grup społecznych, np. dla osób w podeszłym wieku mieszkających samotnie, pracujących w niebezpiecznych warunkach, ale również dla nowoczesnego przemysłu, usług i rolnictwa.

Internet osób (intranet) jest połączony z internetem rzeczy. Komunikacja na linii człowiek-rzecz polega na sprawdzeniu stanu rzeczy lub na wydawaniu rzeczom rozkazów, w skrócie: „włącz”, „wyłącz”, „nastaw”. Tymczasem rzeczy komunikują się z ludźmi w celu przesyłania im ostrzeżeń lub składając im propozycje. Przesyłanie danych jest zapewnione przez 5G, czyli piątą generację telekomunikacji bezprzewodowej. Sieć ta, w swoim założeniu, zapewnia przepływ danych do $20 \mathrm{~Gb} / \mathrm{s}$ w łączu do terminala i do $10 \mathrm{~Gb} / \mathrm{s}$ w łączu do sieci. Dla porównania: stosowana dzisiaj technologia LTE (Long Term Evolution) zapewnia maksymalnie $300 \mathrm{Mb} / \mathrm{s}$ w łączu do terminala, czyli działa ponad 66 razy wolniej. W zależności od scenariusza zastosowania sieć $5 \mathrm{G}$ zapewnia albo wysokie prędkości transmisji danych dla użytkowników mobilnych i stacjonarnych, albo bardzo niskie opóźnienia transmisji (poniżej $1 \mathrm{~ms}$ ) i/lub bardzo wysoką niezawodność niezbędną w zastosowaniach o znaczeniu krytycznym, np. przy kierowaniu autonomicznymi pojazdami, bądź dającą możliwość obsłużenia do miliona urządzeń internetu rzeczy na kilometr kwadratowy.

Dane, a dokładniej gigadane (giga date), ze względu na ilość są przechowywane i przetwarzane w chmurach. Warto przy tym podkreślić, że przetwarzanie w chmurze nie jest szczególnie nową technologią informatyczną, ale raczej nowym modelem biznesowym oferowania sprzętu i oprogramowania na żądanie przez Internet za opłatą proporcjonalną do użytkowania. Spośród trzech aktorów biznesu przetwarzania w chmurze dostawcy chmury, dostawcy usług cyfrowych w chmurze i użytkownika usług cyfrowych - prawdziwą rewolucją stała się ona dla dostawców usług cyfrowych, nie zaś dla samych użytkowników. Tych ostatnich nie interesuje bowiem, czy przetwarzanie danych niezbędnych do oferowania im usługi cyfrowej odbywa się na serwerze będącym własnością dostawcy tej usługi, czy też na serwerach dostawcy chmury. Dostawcy usług cyfrowych wolą przetwarzanie w chmurze niż na własnych serwerach głównie z powodów ekonomicznych, takich jak: możliwość przesunięcia środków finansowych z kosztów inwestycji we własne centra przechowywania i przetwarzania danych na koszty operacyjne usług chmurowych; redukcja kosztów przechowywania i przetwarzania danych dzięki efektowi ekonomii skali; redukcja ryzyka biznesowego dzięki skalowalności rozwiązań w chmurze; poprawa wydajności kosztowej dzięki opłatom proporcjonalnym do użycia; 
redukcja kosztów i zależności od lokalnych informatyków. Zebrane gigadane są przetwarzane za pomocą różnych technik sztucznej inteligencji, zwłaszcza uczenia maszynowego i sieci neuronowych.

Analiza gigadanych jest dziedziną badań, w której wielka skala opisu zjawisk masowych jest konieczna do odkrycia nowej wiedzy - tej wiedzy nie można odkryć w małej skali. Taka analiza jest niezwykle atrakcyjna dla biznesu, ponieważ pozwala - z dużym prawdopodobieństwem, chociaż nie z pewnością - znaleźć igłę w stogu siana i przewidzieć, co się wydarzy w przyszłości. Wiążą się z nią fundamentalne zmiany polegające na zastosowaniu podejścia probabilistycznego, które jednak nie wyklucza dominującego obecnie podejścia deterministycznego. Jeśli linia lotnicza ma wysłać pasażerowi bilet elektroniczny, to musi wysłać mu dokładnie ten bilet, który kupił (podejście deterministyczne), natomiast przy okazji może mu zareklamować kolejną podróż, którą cechuje najwyższe prawdopodobieństwo, że pasażer się w nią uda (podejście probabilistyczne).

W analizie gigadanych mamy do czynienia ze zmianą paradygmatu: od poszukiwania przyczynowości do poszukiwania korelacji. Korelacja między różnymi zbiorami danych nie jest dowodem naukowym, co nie przeszkadza w tym, że w wielu zastosowaniach praktycznych, w których wynik probabilistyczny jest wystarczający, może być podstawą działania biznesowego. Warto jednak podkreślić, że dzięki analizie gigadanych będzie można się dowiedzieć - z wysokim prawdopodobieństwem, chociaż nie z pewnością co się dzieje, a nawet co się stanie w przyszłości, ale już nie - dlaczego to się stanie. Informacja wynikająca z przetworzenia danych i wydobycia z nich nowej wiedzy będzie zwrotnie przesyłana przez internet osób i internet rzeczy, a więc będzie trafiać albo bezpośrednio do osób, albo do rzeczy, które je otaczają - w obu przypadkach wpływając na zachowania osób. Cechą charakterystyczną współczesnej informatyki jest to, że wszelkie technologie składające się na obieg danych stanowią system i dopiero ten system współzależnych i połączonych technologii informatycznych generuje wartość dla społeczeństwa, w tym także wartość ekonomiczną (Cellary, 2019).

W większości państw infrastruktura telekomunikacyjna jest odpowiednia, aby wysyłać e-maile albo wykonać określone zajęcia w Internecie. Gdy jednak używa się Internetu do zadań profesjonalnych lub wysyła się duże ilości danych równocześnie z różnych miejsc, pokazuje on swoje słabości. Mały kod RNA jest niestety silniejszy od człowieka. Człowiek musi więc jeszcze wiele rzeczy nadrobić, a to w nowych warunkach rozwoju, szczególnie w czasie pandemii COVID-19 (Puślecki, 2020b), kiedy istotna jest szybkość i efektywność działań, należy sobie uświadomić. 
W pierwszej fazie pandemii włoscy naukowcy używali sztucznej inteligencji po to, by szybciej diagnozować zdjęcia RTG. Technologia szybkiego przetwarzania lub nawet sztucznej inteligencji przyczyniła się do przyspieszenia badań nad szczepionką. Żadna szczepionka w tak szybkim tempie nigdy nie była wynaleziona. Już samo stawianie diagnozy i wymyślanie skutecznej szczepionki przeprowadzono niezwykle szybko dzięki nowoczesnej technologii zarówno w perspektywie związanej z nauką o wirusach, jak i komunikacyjnej, przetwarzania, współdzielenia i gromadzenia danych. Bez technologii chmurowych i mobilnych oraz sztucznej inteligencji szczepionka przeciwko wirusowi nie mogłaby być tak szybko wynaleziona.

Sztuczna inteligencja jest modelem matematycznym, który ma wiedzę zebraną na podstawie historycznych danych. W przypadku obecnej pandemii nie poradziłaby sobie z nią, ponieważ nie ma danych, na których mogłaby się uczyć. Sztuczna inteligencja to rozpoznawanie pewnych zachowań i wzorców w czasie trwania pandemii COVID-19 (Puślecki, 2020b). Warto zaznaczyć, że można przewidzieć technologię, kupić ją, zaadaptować biznes, zmienić organizację. Czasem jednak pojawia się czynnik, który całkowicie zmienia obraz gry. Jedni nazywają to, za Nassimem Talebem, czarnym łabędziem, kiedyś nazywano to żywiołem. Taki żywioł dotknął świat w 2020 r., a jest nim SARS-CoV-2 (Puślecki, 2020b).

Największą zmianą po pandemii będzie masowa adaptacja chmury obliczeniowej na całym świecie. Widać niesamowity rozwój wszelkiego rodzaju narzędzi pracy zdalnej lub np. wymiany plików na odległość. Sieć informatyczna jest jednak niewydajna, lecz już chmura, w której raz wysyłanym plikiem można się podzielić z jednego miejsca, optymalizując zasoby, jest. AI oraz wszelkiego rodzaju wzory poprawiania efektywności pracy, czyli roboty, automatyzacja procesów, czat-boty, zamienianie słów na komendy to nowe technologie, do których istnienia społeczeństwo będzie musiało się przyzwyczaić.

Druga rzecz wynika z faktu niedotykalnej infrastruktury, np. wszelkich rzeczy związanych ze sterowaniem głosem albo gestami, bądź z własnego urządzenia (ściąganie windy czy zamawianie różnych rzeczy przez telefon komórkowy). Warto zaznaczyć, że zacznie to być codziennością dzisiejszego społeczeństwa. Wdrożeń internetu rzeczy obecnie jest już bardzo dużo, lecz dzielą się one na dwie kategorie. Wdrożeniami pierwszego rodzaju odbiorcy są zachwyceni. Wchodzą one w kulturę i zmieniają nasze zachowania, np. sposób poruszania się po mieście, tu przykładowo hulajnogi i ekonomia współdzielenia zasobów. Internet rzeczy jest podstawą tego, że można coś lokalizować, wypożyczać na chwilę i płacić za to. Takich rozwiązań jest 
bardzo dużo. Są to np. Airbnb (wcześniej Airbed \& Breakfast-bnb-bed and breakfest) czy Uber. Można dodać, że bez internetu rzeczy wypożyczenie samochodu na chwilę, razem z kierowcą lub bez, byłoby niemożliwe.

Adaptacja w świecie, który już działa, w przypadku fabryk i miasta przebiega natomiast słabo. Bardzo trudno jest znaleźć rzeczywisty model biznesowy, który usprawiedliwia używanie nowoczesnej technologii. Wynika to z pierwotnego błędu popełnianego przez przedsiębiorców. Myślą oni bowiem o internecie rzeczy tylko z perspektywy podniesienia produktywności ich przedsiębiorstwa. Bardzo rzadko myślą natomiast o tym, aby równocześnie tworzyć nowe modele biznesowe, które używają danych generowanych przez internet rzeczy. Jest jednak wiele miejsc na świecie, gdzie internet rzeczy zmienił całkowicie sposób prowadzenia biznesu. Są to np. wielkie porty czy lotniska, na których inaczej wygląda obecnie sposób zarządzania ruchem (Poniewierski, 2020).

Pojawia się pytanie, na ile nowe technologie zmienią biznes? Odpowiedzieć można jednym słowem - całkowicie. Warto zaznaczyć, że dwadzieścia lat temu było nie do pomyślenia, aby użytkownik mieszkania wypożyczał je, gdy wyjeżdża na urlop. Dzisiaj krótkotrwały najem jest czymś naturalnym. Jest to właśnie nowy model biznesowy. Dla młodych osób dzielenie się zasobami albo używanie ich na odległość jest kwestią naturalną.

Potężna zmiana nastąpi po wdrożeniu sieci piątej generacji - 5G. Wówczas powstanie zupełnie inny model przesyłania danych, zarządzania infrastrukturą w czasie rzeczywistym. Będą to np. modele płacenia za używanie jakiegoś przedmiotu podstawowej potrzeby. Coraz częściej spotykanym modelem jest freemium. Pięć lat temu nie było go jeszcze na świecie. Model ten daje za darmo całą aplikację czy rozwiązania, ale analizuje zachowanie użytkownika podczas jego używania. Na podstawie tego schematu proponuje użytkownikowi opłaty. Często mylony jest z modelem premium. Freemium to model, gdzie wszystko jest za darmo, AI analizuje zaś zachowanie użytkownika i podsuwa możliwości dopłacania za pewne usługi. Jest to zatem niesamowity model biznesowy, na podstawie którego powstaje kapitalizm inwigilacyjny.

Należy zauważyć, że wraz z pojawianiem się kolejnych nowych technologii mogą wzrastać nadużycia. Przestępcy np. mogą wyłączyć nagle krajową sieć piątej generacji 5G, w konsekwencji czego zatrzymuje się wszystko, ponieważ wszystkie urządzenia są do niej podłączone. Takie obawy mogą być uzasadnione. Jednakże na szczęście duża część infrastruktury krytycznej jest nadal analogowa. Na wypadek poważnego włamania do sieci istnieją mosty analogowe. Jeżeli zaś koncepcją całej sieci będzie 
zarządzać „cyfrowa głowa”, ryzyko będzie o wiele większe. Ryzyko jest widoczne na trzech poziomach. Po pierwsze, włamywacz może przełamać zabezpieczenia, po drugie, może mieć dostęp do kodów odpowiadających za to, jak zachowuje się cała infrastruktura (mogą tam być ukryte nieprzewidywalne elementy, a przez skomplikowanie algorytmów niewykrywalne), po trzecie, ryzyko może stanowić niezauważony błąd człowieka. AI na bazie tego błędu będzie się uczyć i dojdzie do efektu kuli śnieżnej. W pewnym momencie malutki błąd AI będzie traktować jako poprawny wzorzec i na jego bazie wygeneruje poważny problem. Na takie działanie obecnie nie ma rozwiązania. W czwartej rewolucji przemysłowej nikt nie wymyślił jeszcze patentu na bezpieczeństwo (Poniewierski, 2020).

W kontekście rozważanych kwestii można zauważyć, że bezpieczeństwem tłumaczy się wprowadzanie takich technologii jak rozpoznawanie twarzy, np. w Chinach system nadzoru, czyli inwigilacja społeczeństwa, jest bardzo rozpowszechniony. Bezpieczeństwem można tłumaczyć wiele działań. Jeżeli pojawiają się określone obawy, należy je w miarę możliwości zidentyfikować, zrozumieć i monitorować. Po atakach na World Trade Center i Pentagon w Stanach Zjednoczonych w imię bezpieczeństwa społeczeństwo łatwo pogodziło się z dodatkowymi, bardzo restrykcyjnymi kontrolami na lotniskach. Warto zaznaczyć, że na początku XXI w. istniała pokusa jeszcze głębszej inwigilacji, ale nie była możliwa do zrealizowania. W 2020 r. już stała się faktem, ponieważ jest to działanie tanie i szybkie (Poniewierski, 2020).

W przypadku Chin dochodzi ponadto element kulturowy. Monitorowanie jest w tej części świata powszechnie akceptowane. Ale to, na co należy zwrócić uwagę, to nie sam fakt monitorowania, lecz model wykorzystania tych danych do uczenia algorytmów sztucznej inteligencji. Tak wielkiej bazy zachowań jak Chiny nie ma nikt na świecie, a jak wiadomo, dla AI ważne są trzy elementy: moc obliczeniowa, algorytmy i dane. Dwa pierwsze są powszechnie dostępne i tanie. Trzeci to skarb, na którym rośnie przyszły Banyan Tree (określenie nawiązujące do bardzo cennego dającego cień drzewa banyan).

Polskie społeczeństwo jest znaczącym użytkownikiem nowej technologii. Polska jej nie produkuje, nie można więc powiedzieć, że znajduje się w czołówce nowoczesnych rozwiązań. W naszym kraju jest wiele osób, które potrafią tę technologię sprawnie stosować. Adaptacja technologiczna w Polsce jest zatem bardzo wysoka. Nie ma drugiego miejsca na świecie, gdzie tak popularne są karty płatnicze czy używanie do płacenia telefonu. Społeczeństwo polskie jest fantastyczne w wykorzystywaniu technologii 
w rozumieniu funkcjonalnym. Jest wielu zdolnych programistów i projektantów systemów informatycznych, którzy pracują zazwyczaj dla firm zachodnich na zasadzie delokalizacji usług, czyli outsourcingu.

Biorąc po uwagę znaczenie sztucznej inteligencji i internetu rzeczy dla przyszłego rozwoju, należy podkreślić konieczność posiadania odpowiedniej edukacji: AI należałoby wprowadzić już do szkół podstawowych (Poniewierski, 2020). Taką edukację trzeba rozwijać, a to powinno być wspierane przez rząd, administrację i biznes. W rezultacie za kilkanaście lat społeczeństwo będzie zdolne do tworzenia rzeczy nieprzeciętnych. Polska myśl technologiczna i naukowa powinna się więc skoncentrować na wykorzystaniu technologii przede wszystkim w nowoczesnym biznesie.

Istotny jest fakt, że do końca roku 2022 aż 67\% menedżerów z całego świata zamierza zainwestować w internet rzeczy, 64\% w sztuczną inteligencję, a $61 \% \mathrm{w}$ rozwiązania chmurowe, co wynika z badania firmy doradczej EY nazwanego „Digital Investment Index 2020”. Zdecydowanie mniejszym zainteresowaniem cieszą się natomiast rozwiązania z zakresu blockchain, cyberbezpieczeństwa, inteligentnej automatyzacji procesów czy rozszerzonej rzeczywistości. Sandbox Blockchain pozwoli użytkownikom skorzystać z bezpiecznej przestrzeni do praktycznego i szybkiego prototypowania aplikacji i testowania nowych rozwiązań z innymi uczestnikami rynku. Chmura krajowa jest natomiast partnerem technologicznym projektu (Internet Rzeczy..., 2020).

Transformacja cyfrowa pozwala nie tylko na dynamiczny rozwój, ale i na zwiększenie odporności przedsiębiorstw na różne rodzaje ryzyka. Firmy przekonały się o tym w ostatnich kwartałach 2020 r., kiedy pandemia COVID-19 niejako wymusiła na nich adaptację nowych technologii (Puślecki, 2020b). W tym przełomowym czasie wykorzystanie narzędzi cyfrowych wielu firmom pozwoliło działać podczas lockdownu, a najnowsze rozwiązania technologiczne usprawniły m.in. analizę, transfer i przechowywanie danych, pozwalając reagować na dynamicznie zmieniające się wyzwania. Liderzy cyfrowej transformacji zwiększyli swoją odporność, a tym samym przewagę rynkową wobec tych, którzy transformację cyfrową wciąż realizują na niewielką skalę bądź decydują się wyłącznie na implementację pojedynczych technologii i rozwiązań (Internet Rzeczy..., 2020).

Liderzy cyfrowej transformacji preferują przede wszystkim rozwój cyfrowych kompetencji na drodze fuzji, przejęć czy partnerstw. Takie podejście prezentuje 64\% firm. Ponad połowa transformacyjnych liderów zamierza koncentrować się na uzyskaniu szybkich zwrotów z wdrożonych rozwiązań, 49\% zamierza porzucić inicjatywy, które nie są konieczne, 
a 46\% przyspieszyć rozwój nowych, cyfrowych produktów i usług, a także modeli biznesowych.

Należy zaznaczyć, że aż 79\% ankietowanych przez EY deklaruje, że ich działania dotyczące transformacji cyfrowej grzęzną w początkowej fazie. Dzieje się tak ze względu na brak odpowiednich umiejętności pracowników (na tę kwestię wskazuje 65\% ankietowanych), brak wystarczającego budżetu i finansowania (59\%) lub odpowiedniego modelu operacyjnego (45\%). Jedna trzecia nie ma z kolei dostępu do danych (Internet Rzeczy..., 2020).

Z badania wynika ponadto, że $45 \%$ firm nie ma odpowiedniego modelu operacyjnego zakładającego procesy cyfryzacji, a 38\% mierzy się z brakiem strategii w tym zakresie. W 36\% firm brakuje kultury innowacji i eksperymentowania, a 34\% mierzy się z coraz większym naciskiem na cięcie kosztów. Zdaniem analityków EY może to tłumaczyć, dlaczego prawie $10 \%$ respondentów badania (w tym również liderzy cyfrowej transformacji) deklaruje, że nie jest w stanie odczuć w pełni efektu swoich wysiłków podjętych na rzecz cyfryzacji przedsiębiorstw (Internet Rzeczy..., 2020).

W naszym kraju Komitet Rady Ministrów ds. Cyfryzacji (KRMC) w połowie września 2020 r. przyjął dokument pod nazwą „Polityka rozwoju sztucznej inteligencji w Polsce”. Zakłada on m.in. wsparcie sektora publicznego w realizacji zamówień na rzecz sztucznej inteligencji. Resort cyfryzacji zwrócił uwagę, że nowe technologie i rozwiązania wykorzystujące sztuczną inteligencję mają coraz większy wpływ na budowanie potencjału narodowych gospodarek. „Polska także chce tę szansę wykorzystać. «Polityka rozwoju sztucznej inteligencji» ma pomóc w realizacji tego zamierzenia”podkreślono w komunikacie KRMC.

Ministerstwo wyjaśniło, że przyjęty przez KRMC dokument uzupełnia m.in. Strategię Odpowiedzialnego Rozwoju. Określa działania i cele dla Polski w zakresie AI w perspektywie krótko- (do 2023 r.), średnio(do 2027 r.) i długoterminowej (po 2027 r.). Cele te podzielone zostały na sześć obszarów. Pierwszym z nich jest „AI i społeczeństwo”, określający działania, które mają uczynić z Polski jednego z większych beneficjentów gospodarki opartej na danych, a z Polaków - społeczeństwo świadome konieczności ciągłego podnoszenia kompetencji cyfrowych. Kolejnym jest „AI i innowacyjne firmy”, który przewiduje wsparcie polskich przedsiębiorstw AI m.in. przez tworzenie mechanizmów finansowania ich rozwoju, współpracy start-upów z rządem. Trzecim obszarem jest „AI i nauka”, w którym identyfikuje się wsparcie polskiego środowiska naukowego i badawczego w projektowaniu interdyscyplinarnych wyzwań lub rozwiązań w obszarze sztucznej inteligencji. Następnym obszarem jest „AI i edukacja”, w ramach 
którego zakłada się działania podejmowane od kształcenia podstawowego aż do poziomu uczelni wyższych. Przewiduje on programy kursów dla osób zagrożonych utratą pracy na skutek rozwoju nowych technologii oraz granty edukacyjne. Piąty obszar „AI i współpraca międzynarodowa” przewiduje działania na rzecz wsparcia polskiego biznesu w zakresie sztucznej inteligencji oraz rozwój technologii na arenie międzynarodowej. Ostatni temat „AI i sektor publiczny” zakłada wsparcie sektora publicznego w realizacji zamówień na rzecz sztucznej inteligencji, lepszej koordynacji działań oraz dalszego rozwoju takich programów jak GovTech Polska (Rzq̨d przyjął strategię..., 2020).

Strategia AI przewiduje pomoc Unii Europejskiej w jej realizacji. Minister cyfryzacji Marek Zagórski podkreślił, że polityka rozwoju sztucznej inteligencji w Polsce zakłada również stworzenie, w ramach struktur rządu, centrum koordynacyjnego przy resorcie cyfryzacji, którego celem będzie monitorowanie wdrożenia polityki AI w Polsce oraz koordynacja działań partnerów.

„Zadaniem centrum będzie także skoordynowanie rozproszonych źródeł finansowania w budżecie państwa, programach pomocowych, w tym Unii Europejskiej, a także funduszy inwestycyjnych w celu dedykowania środków na badania, rozwój i inwestycje na rzecz rozwoju sztucznej inteligencji w Polsce” (Rzq̨d przyjął strategię..., 2020). Ministerstwo podkreśliło, że przyjęty przez Komitet Rady Ministrów ds. Cyfryzacji dokument jest efektem wielomiesięcznych konsultacji. Pierwszy projekt poddano konsultacjom publicznym i prekonsultacjom rządowym w sierpniu i wrześniu 2019 r. Wzięło w nich udział 46 podmiotów. Następnie, w lutym i marcu 2020 r., przeprowadzono dalsze konsultacje, w tym międzyresortowe, eksperckie i społeczne. W lipcu 2020 r. „Polityka rozwoju sztucznej inteligencji” została wpisana do wykazu prac legislacyjnych rządu z pozytywną opinią Centrum Analiz Strategicznych. Resort poinformował, że dokument zostanie przekazany do dalszych prac legislacyjnych. Został przyjęty przez Stały Komitet Rady Ministrów na przełomie września i października 2020 r. (Rzq̨d przyjął strategię..., 2020).

\section{Budowa sieci piątej generacji (5G)}

Według danych GSMA-Global System for Mobile Communications w 2020 r. na świecie działało 107 komercyjnych sieci 5G (w tym 27 w Europie), które obejmują zasięgiem 7\% światowej populacji. Z kolei, 
jak wynika z analiz Ericssona, rozwój 5G na całym świecie będzie szybszy niż podczas wprowadzania LTE (Long Term Evolution). Do 2025 r. 88\% subskrypcji mobilnych (około 8,9 mld) będzie realizowanych w technologii piątej generacji. Pod tym względem $5 \mathrm{G}$ najszybciej rozwinie się w Ameryce Północnej, we wschodniej Azji i w Europie Zachodniej. W Europie Centralnej i Wschodniej dominującym rozwiązaniem pozostanie jeszcze przez dłuższy czas LTE, które do 2025 r. pokryje 66\% subskrypcji, prawie całkowicie zastępując starsze generacje łączności. W Europie Centralnej i Wschodniej 27\% rynku w bliskiej perspektywie ma zagospodarować 5G (Tomczyk, 2020).

Rozwój sieci to także urządzenia (rutery i smartfony) obsługujące łączność piątej generacji. O ile sprzęt już wcześniej wchodził na rynek, dopiero w 2020 r. pojawił się szerszy wybór urządzeń, które działają na różnych częstotliwościach. Obecnie głównym motorem dla 5G jest pandemia COVID-19 (Puślecki, 2020b) - wielu operatorów postanowiło zmodernizować swoją infrastrukturę, aby obsłużyć zwiększone zapotrzebowanie na transfer sieciowy. Coraz częściej pracuje się zdalnie i korzysta z multimediów, przesyłając przez Internet nie tylko dźwięk, lecz także obraz. To z kolei coraz mocniej obciąża sieć (analitycy mówią o dwukrotnym wzroście ruchu internetowego) (rys. 1). Po pandemii ten trend ma nie zniknąć i do 2025 r. 76\% transferu sieciowego będzie związane z przesyłaniem obrazu wideo (Tomczyk, 2020).

Paradoksalnie to zwiększone zapotrzebowanie jednocześnie nieco zahamowało rozwój technologii związanych z internetem rzeczy, który ciągle opiera się na 2G i 3G. Niemniej do 2025 r. co trzecie połączenie IoT na świecie zostanie obsłużone przez 4G. W 2021 r. pojawiły się elementy infrastruktury krytycznej internetu rzeczy, pozwalające realizować usługi, które wymagają bardzo niskich opóźnień. Dużo w tym względzie zależy od operatorów i od procesu przyznawania częstotliwości przez Urząd Komunikacji Elektronicznej.

Należy podkreślić, że sieć mobilna rozwija się w Polsce od trzydziestu lat. Pierwsza generacja została uruchomiona w Polsce w 1992 r. i oferowała na początku jedynie połączenia głosowe. Cztery lata później, kiedy wprowadzono sieć $2 \mathrm{G}$, pojawiły się nowe usługi, takie jak SMS-y i transmisja danych, która początkowo charakteryzowała się bardzo wolnym transferem. Mimo to sieć 2G i standard GSM (fr. Groupe Spécial Mobile), obecnie GSMC (Global System for Mobile Communications) posłużyły do pierwszych mobilnych zastosowań M2M (ang. machine to machine), w rodzaju opracowanego przez Samsunga modułu M1 wykorzystywanego w terminalach 


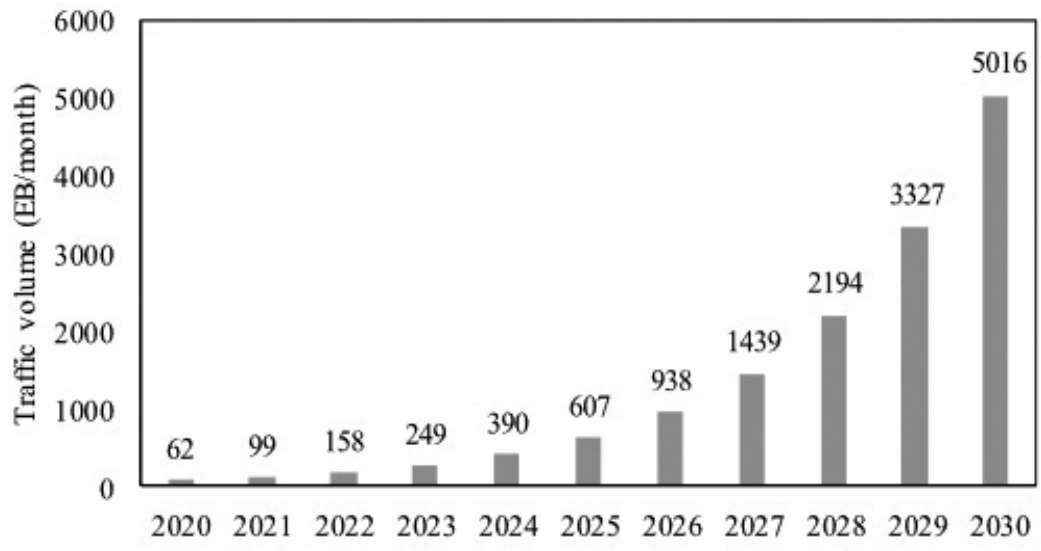

(a)

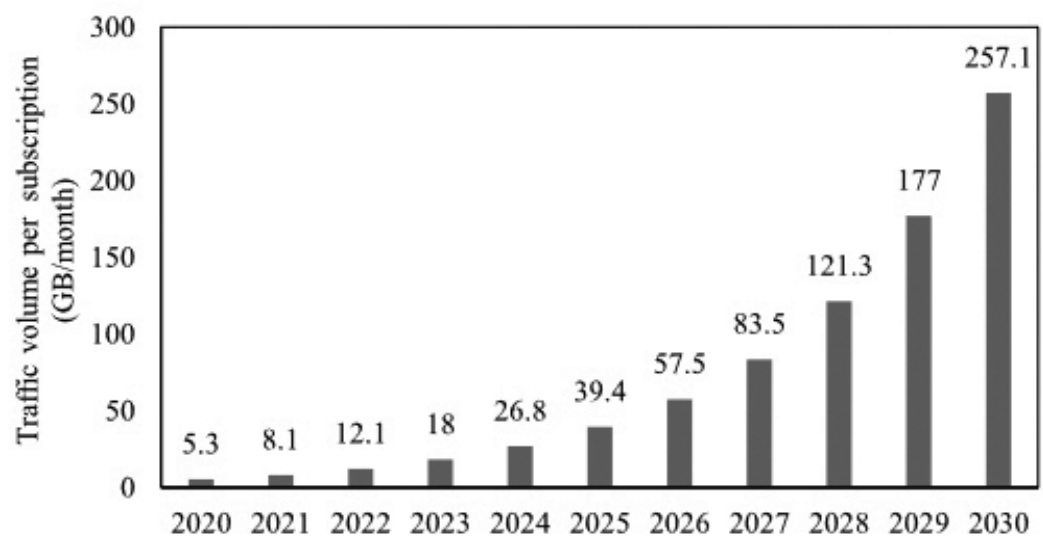

(b)

a) Całkowity globalny transfer mobilny

b) Transfer mobilny według subskrypcji (abonamentu)

Rysunek 1. Przewidywany wykładniczy wzrost zapotrzebowania na transfer mobilny w latach 2020-2030.

Źródło: IEEE - Institute of Electrical and Electronics Engineers, 2020, https://przemyslprzyszlosci.gov.pl/5g-klucz-do-przemyslowej-przyszlosci

(dostęp: 12.01.2021) 
POS (point of sale - punkt handlowy; urządzenie instalowane w punktach handlowo-usługowych), telematyce i zdalnym monitoringu (Tomczyk, 2020).

W rozwoju sieci mamy do czynienia z ewolucją i dokładaniem kolejnych usług do istniejącej infrastruktury. Wiele państw zdecydowało o pozostawieniu 2G jako zapasowego systemu łączności. Należy zaznaczyć, że takie rozwiązanie wydaje się rozsądne, ponieważ standard GSM to w zasadzie wszystkie podstawowe usługi, które można wykorzystać np. podczas klęsk żywiołowych, w tym COVID-19 (Puślecki, 2020b), a jego zaletą jest to, że działają w nim także starsze urządzenia. Równolegle operatorzy modernizują stacje bazowe, poprawiając przepustowość i zmniejszając opóźnienia oraz dodając nowe usługi. Ponieważ przejście do kolejnej generacji łączności mobilnej nie następuje skokowo, w ramach jednej infrastruktury mogą koegzystować różne standardy, co powoduje, że użytkownicy nie muszą martwić się o kompatybilność urządzeń. W 2004 r. w Polsce pojawiła się sieć 3G, która wprowadziła usługi multimedialne, a użytkowników w erę smartfonów. Każda kolejna generacja poprawia parametry połączeń mobilnych i transferu danych. Od 2010 r. korzysta się z LTE, które pozwoliło zwiększyć kilkunastokrotnie prędkość przesyłu w stosunku do 3G. Po nadchodzącym 5G można się spodziewać lepszej stabilności i nawet sto razy większej pojemności sieci niż w przypadku czwartej generacji. A 6G (najwcześniej za około dziesięć lat) najpewniej wprowadzi dzisiejsze społeczeństwo w erę postsmartfonów i sprawi, że urządzenia internetu rzeczy staną się doskonalsze i sprytniejsze dzięki algorytmom sztucznej inteligencji (rys. 2).

Należy zaznaczyć, że są dwie drogi, które mogą wybrać operatorzy wprowadzający 5G. Mogą od razu postawić na 5G SA (StandAlone), czyli samodzielną sieć piątej generacji wyposażoną we wszystkie funkcje i cechy tej technologii, albo zastosować model przejściowy 5G NSA (NonStand Alone), oparty na infrastrukturze sieci 4G. Podobnie wyglądało przejście z architektury 2G na 3G i z 3G na LTE. Polscy operatorzy wybrali drugi wariant jako łatwiejszy do wprowadzenia, również ze względu na to, że UKE nie przydzielił jeszcze pasm $700 \mathrm{MHz}, 3,6 \mathrm{GHz}$ i $26 \mathrm{GHz}$. Tymczasem nastąpił tzw. refarming, a zatem zwolnienie pasma $700 \mathrm{MHz}$ przez stacje telewizyjne. W większości przypadków widzowie nawet tego nie zauważyli, ponieważ nowsze odbiorniki same się przestroiły, tylko użytkownicy starszych telewizorów musieli dostosować urządzenia ręcznie (Tomczyk, 2020).

Piąta generacja sieci telekomunikacyjnej zapewni przede wszystkim, o czym była już mowa, szybszy dostęp do Internetu. Ponadto poziom latencji, czyli opóźnień w połączeniach i ich nawiązywaniu, ma zostać zredukowany do zaledwie kilku milisekund, a stabilność samego połączenia ma 


\section{SIECI MOBILNE W POLSCE}

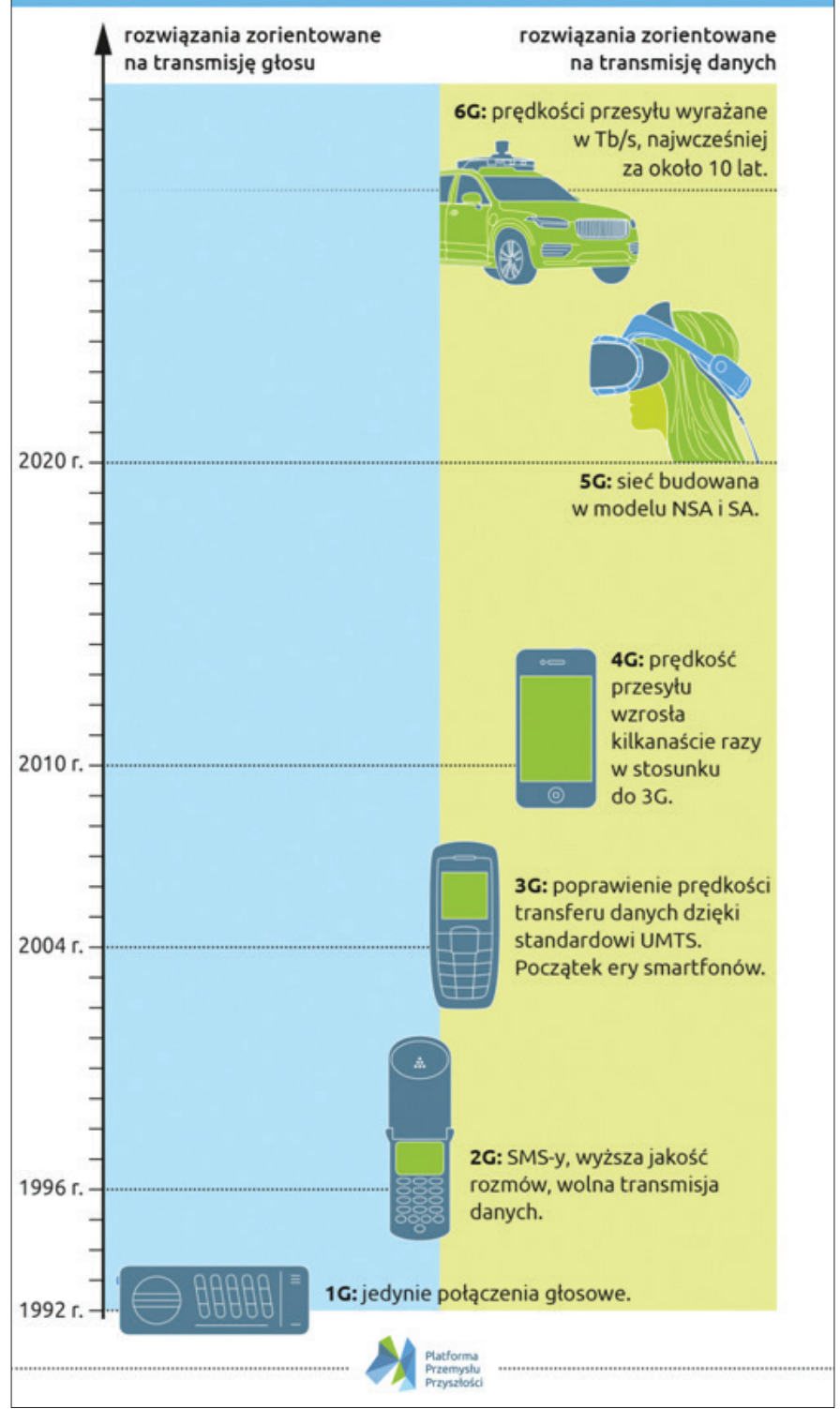

Rysunek 2. Sieci kolejnych generacji jako udoskonalenie już istniejących technologii mobilnych.

Źródło: GSMA - Global System for Mobile Communications, 2020, https://przemyslprzyszlosci.gov.pl/5g-klucz-do-przemyslowej-przyszlosci (dostęp: 12.01.2021). 
być utrzymywana z prędkością do $500 \mathrm{~km} / \mathrm{h}$. Z kolei możliwa jednoczesna obsługa urządzeń bazujących na technologii mobilnej ma wzrosnąć do liczby miliona w obrębie tylko $1 \mathrm{~km} \mathrm{kw.}$

Aby wdrożyć nową technologię, niezbędne będzie zastosowanie nowych nadajników i anten, które pozwolą z czasem na wykorzystywanie fal radiowych, m.in. w paśmie od $700 \mathrm{MHz}$ do nawet $26 \mathrm{GHz}$. Oprócz tego sieć będzie obsługiwać także pasma częstotliwości z poprzednich generacji i przebudowywać istniejące anteny. Zmianie nie ulegnie sposób transmisji radiowej. Konstrukcyjnie nadajniki obsługujące 5G mają być znacznie mniejsze i znajdować się np. w latarniach czy na przystankach. Oznacza to, że moc sygnałów będzie zyskiwana za pomocą gęstości rozmieszczenia, a nie rozmiaru samego urządzenia, przez co wytwarzana energia elektryczna będzie mniejsza w przeliczeniu na jeden egzemplarz.

Pojawienie się sieci 5G przyniesie również oszczędności finansowe oraz zminimalizuje emisję szkodliwych związków. W rezultacie takie rozwiązanie przyniesie poprawę zarówno na polu ekonomicznym, jak i ekologicznym. Należy podkreślić znane twierdzenie, że bez rozwoju nie można mówić o postępie. Jeżeli zatem społeczeństwo zamierza w przyszłości doświadczyć np. bezpiecznej jazdy samochodem autonomicznym lub korzystać z funkcjonalności internetu rzeczy, a przede wszystkim dalej wygodnie i swobodnie korzystać z sieci streamingu, musi zaakceptować ten fakt. Wbrew wyobrażeniom o nieskończoności Internetu, trzeba przyznać, że przepustowość obecnej sieci nie jest nieograniczona (Czym jest technologia 5G..., 2020).

Trzeba jednak zwrócić uwagę na to, że ze względów bezpieczeństwa niektóre usługi będą możliwe do zrealizowania dopiero po wprowadzeniu samodzielnego 5G. Stabilność sieci i niskie opóźnienia są konieczne m.in. do rozwoju autonomicznych pojazdów czy do prowadzenia operacji chirurgicznych na odległość. W obu przypadkach nawet niewielkie opóźnienie mogłoby skończyć się tragicznie. Jest jednak wiele zastosowań, w których 5G NSA sprawdzi się znakomicie (Tomczyk, 2020).

Nie bez znaczenia jest podkreślenie, że sieć 5G, podobnie jak poprzednie generacje sieci komórkowych, powstała w odpowiedzi na coraz większe zapotrzebowanie na transfer danych. Ulepszone stacje bazowe oraz szybsze urządzenia końcowe pozwolą w dalszym ciągu rozwijać infrastrukturę inteligentnych miast oraz internetu rzeczy. Wszystkie te urządzenia skorzystają z niezwykle szybkiego, stabilnego oraz - co ważne - przystępnego cenowo połączenia z Internetem. Dzięki sieci nowej generacji będzie można pozbyć się problemu z przeciążeniem sieci i nagłymi spadkami wydajności 
w obszarach mocno zaludnionych. Ważne jest też wskazanie, że w nowej generacji sieci 5G łączność będzie znacznie stabilniejsza podczas poruszania się. Skorzystają na tym np. autonomiczne i półautonomiczne samochody, które nie będą już miały problemu z podtrzymaniem łączności z siecią i infrastrukturą drogową (Olszewski, 2020).

Najbliższa przyszłość sieci $5 \mathrm{G}$ będzie bezpośrednio powiązana z budowaniem kolejnych stacji bazowych, które pozwolą na zwiększenie pokrycia zasięgiem sieci nowej generacji. W 2021 r. z możliwości sieci 5G będzie można skorzystać w siedmiu miastach w Polsce: w Warszawie, Gdańsku, Szczecinie, Poznaniu, Wrocławiu, Łodzi oraz Katowicach. Ze względu na specjalny dobór miejsc, w których umieszczono nadajniki (przy ważnych punktach przesiadkowych / w centrach miast / przy atrakcjach turystycznych), w zasięgu sieci 5G jest około miliona Polaków (Olszewski, 2020). W najbliższym czasie świadomość społeczeństwa o sieci 5G będzie się zwiększać. Po pierwszych testach okazało się już, że sieć 5G oferuje znacznie szybszy przesył danych i mniejsze opóźnienia. Tak więc w niedalekiej przyszłości będzie można skorzystać ze znacznie szybszej i dostosowanej do aktualnych potrzeb sieci telefonii komórkowej (Olszewski, 2020).

Warto zaznaczyć, że o ile na początku połączenia M2M wykorzystywały w niewielkim stopniu przesył danych, o tyle w 2020 r., wraz z rozwojem sieci mobilnej i koncepcji internet of things, zapotrzebowanie na transfer rośnie w tempie wykładniczym (rys. 1). Coraz więcej urządzeń komunikuje się ze sobą, a to ma przełożenie zarówno na rynek konsumencki, jak i firmy produkcyjne czy logistyczne, które coraz częściej automatyzują swoją działalność. Z tego powodu rozwój sieci mobilnej jest koniecznością, bez wprowadzenia nowych generacji nie byłaby bowiem możliwa realizacja takich celów, jak inteligentne fabryki i miasta. Internet rzeczy jest rozwinięciem koncepcji M2M, a oba rozwiązania różni skala. Wykorzystanie pojemnych i stabilnych sieci najnowszych generacji pozwoli komunikować się znacznie większej liczbie urządzeń. Osiągalne staną się zadania, które wymagały dotąd kilku usług (rys. 3).

Technologiami, które szczególnie zyskają na znaczeniu w ciągu najbliższych lat za sprawą rozwoju 5G, są wirtualna i rozszerzona rzeczywistość. Zestawy VR (rzeczywistość wirtualna) i AR (rzeczywistość rozszerzona) znajdą zastosowanie na rynku konsumenckim, w biznesie oraz produkcji. Do tej pory praca zdalna dotyczyła głównie pracowników biurowych, tymczasem 5G i wirtualna rzeczywistość umożliwiają wykonywanie obowiązków służbowych z domu również operatorom i konserwatorom sprzętu, co było widoczne szczególnie w czasie pandemii COVID-19 (Puślecki, 2020b). 


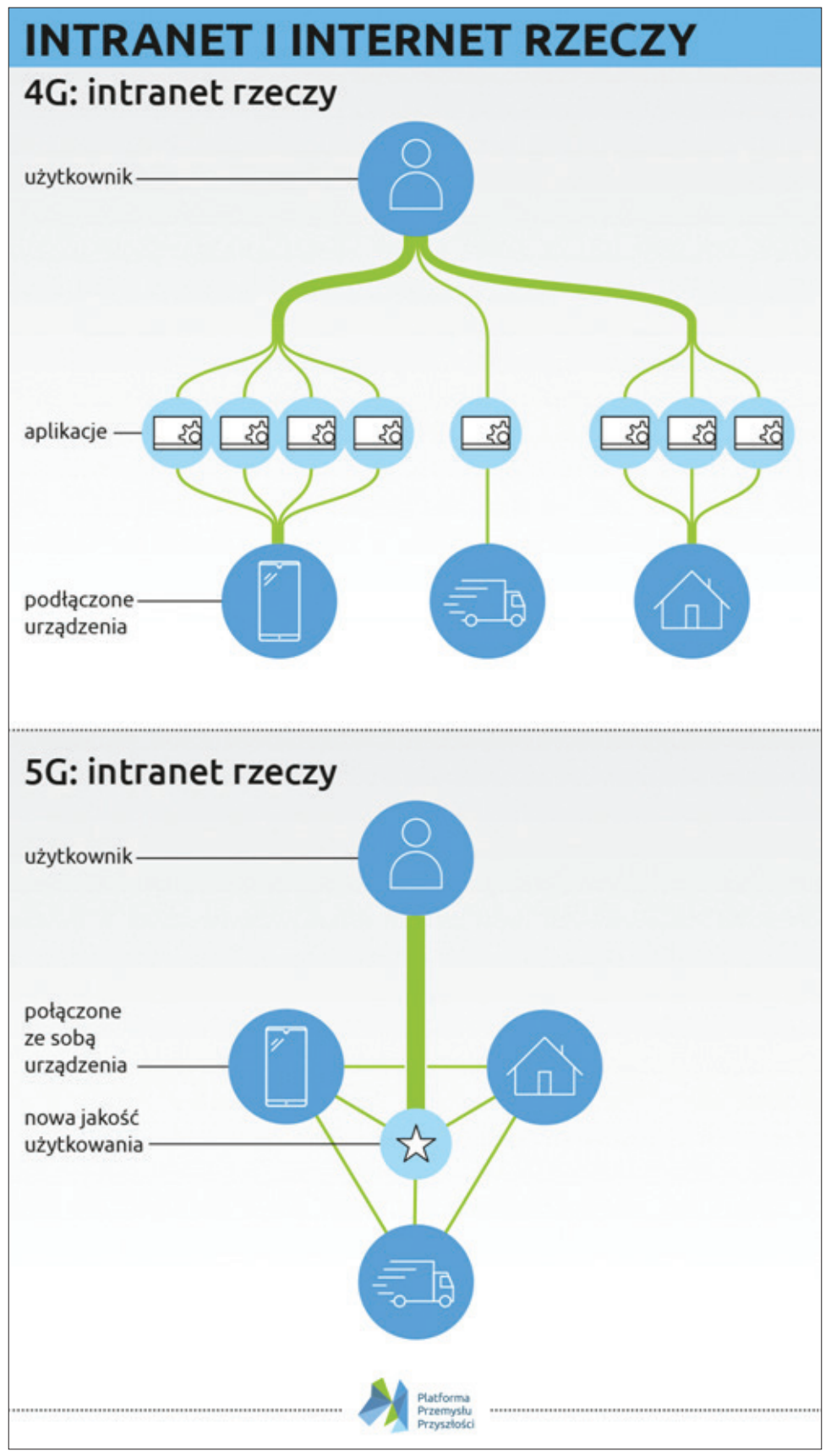

Rysunek 3. Intranet oraz internet rzeczy.

Źródło: Tomczyk, 2020. 
Specjalista siedzący w domu połączy się za pomocą aplikacji (np. TeamViewer Pilot) i zaznaczy na obrazie transmitowanym z Google mieszanej rzeczywistości, używanej przez pracownika fabryki, co ten powinien po kolei robić, aby naprawić urządzenie. Aby realizacja takiego scenariusza była możliwa, konieczne jest stabilne połączenie z niskimi opóźnieniami oraz szybkim transferem. Te wszystkie cechy ma sieć piątej generacji (rys. 4) (Tomczyk, 2020).

W Polsce Ministerstwo Cyfryzacji opublikowało Białą Księgę 5G, z której można dowiedzieć się o szczegółach technicznych dotyczących tej technologii. Eksperci z Państwowego Instytutu Łączności rozwiewają wątpliwości na temat zjawisk fizycznych związanych z 5G. W ostatnim czasie rozpowszechniło się wiele mitów na temat sieci piątej generacji, dlatego warto zapoznać się z rzetelnymi informacjami. Z Białej Księgi 5G można dowiedzieć się m.in., że promieniowanie radiowe i mikrofalowe (w przeciwieństwie chociażby do promieniowania rentgenowskiego) nie jonizuje materii, co oznacza, że nie ingeruje w budowę komórek organizmów żywych i nie wpływa na ich funkcje. Co więcej, w przypadku tego rodzaju promieniowania elektromagnetycznego nie występuje efekt kumulacji.

Mimo braku dowodów na szkodliwość niejonizującego promieniowania elektromagnetycznego obowiązują jednak normy natężenia PEM (pola elektromagnetycznego). W Polsce przez wiele lat były one bardzo restrykcyjne, blokując rozwój infrastruktury telekomunikacyjnej. Na początku $2020 \mathrm{r}$. sytuacja zmieniła się i normy zostały dostosowane do obowiązujących na terenie Unii Europejskiej. Dzięki temu jest możliwe uruchomienie sieci piątej generacji, która pozwala udostępnić nowe usługi i zwiększać konkurencyjność polskiej gospodarki.

Warto dodać, że także ludzkie ciało jest źródłem pola elektromagnetycznego. Energia fotonów stale emitowanych przez ludzką skórę jest milion razy większa niż energia fal radiowych i mikrofalowych. To zjawisko jest powszechnie wykorzystywane w medycynie do badaniach fal mózgowych (EEG) i monitorowania pracy serca (EKG). Co więcej, jako ludzie jesteśmy wyposażeni w biologiczne detektory pola elektromagnetycznego. Bardzo dokładnym „przyrządem” jest skóra wyczuwająca promieniowanie podczerwone, czyli ciepło. Z kolei zmysł wzroku pozwala rejestrować fotony w zakresie światła widzialnego, które również zalicza się do PEM.

Pole elektromagnetyczne jest jednym z fundamentalnych elementów świata przyrody, występuje w pobliżu wszystkich cząstek naładowanych elektrycznie, przemieszczających się ładunków czy magnesów stałych. 


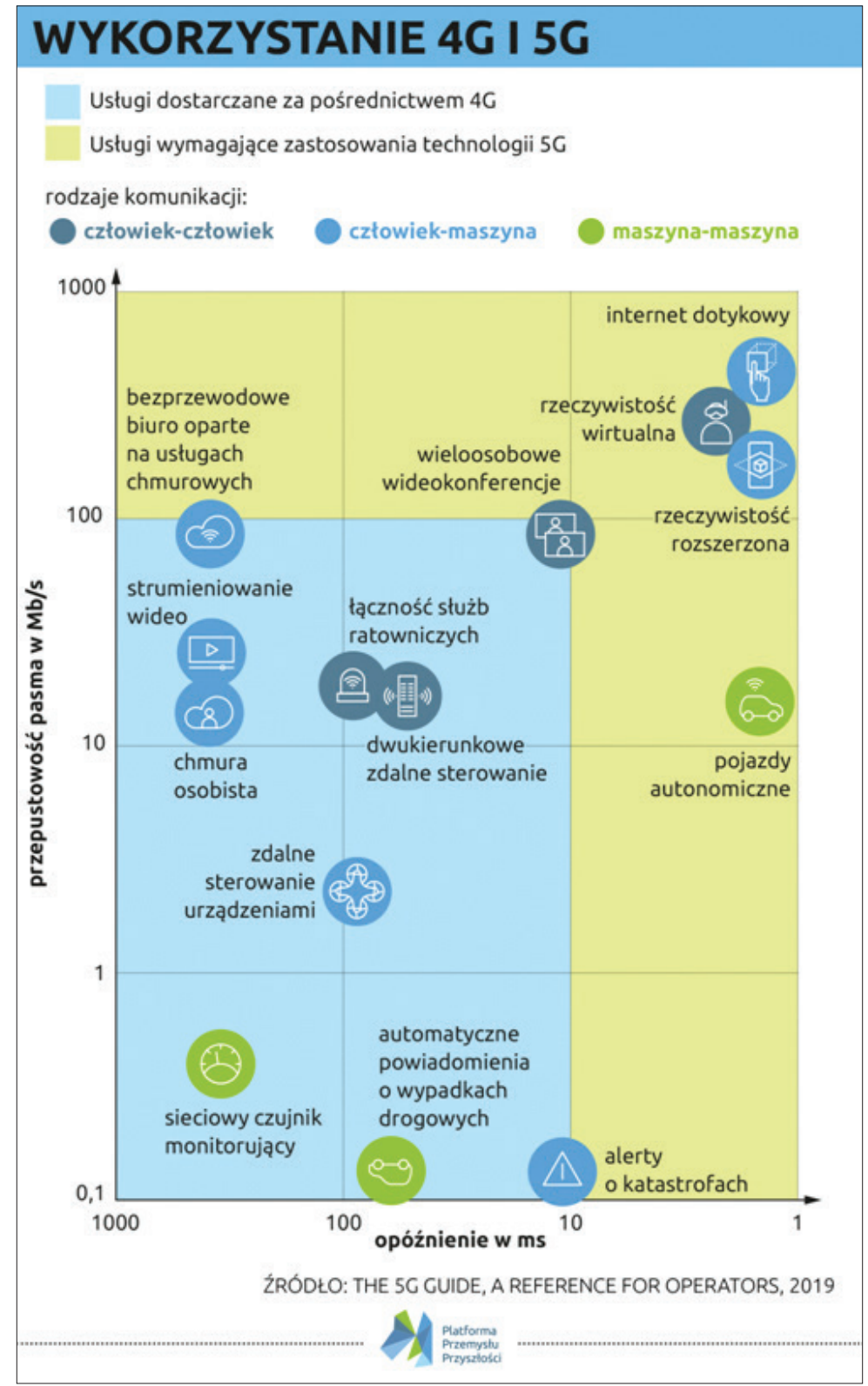

Rysunek 4. Usługi w 4G i 5G.

Źródło: Tomczyk, 2020. 
Fale elektromagnetyczne otaczają ludzi zewsząd, a ich źródło może być zarówno naturalne (np. Słońce), jak i wytwarzane przez każde działające urządzenie elektryczne. Telewizor, suszarka do włosów, lodówka, płyta indukcyjna, laptop czy telefon komórkowy są więc źródłem promieniowania elektromagnetycznego (Tomczyk, 2020).

Należy zwrócić uwagę na jeszcze jeden aspekt: poszczególne mikrokomórki, czyli gęsto rozlokowane nadajniki 5G, mają zdecydowanie mniejszą moc niż jeden nadajnik o dużej mocy, który pokryłby ten sam obszar. Wbrew temu, co w pierwszej chwili może podpowiadać intuicja, w przypadku mikrokomórek mamy zatem do czynienia z dużo mniejszym natężeniem PEM w pobliżu nadajnika. Taki model pozwala też ograniczyć moc sygnału wytwarzanego przez urządzenie końcowe (np. telefon).

Istotne jest, że kolejnym etapem rozwoju sieci i internetu rzeczy będzie włączenie algorytmów sztucznej inteligencji do infrastruktury sieciowej). Takie rozwiązanie prawdopodobnie stanie się konieczne, aby udało się zapanować nad ogromnymi ilościami danych, jakie trzeba przetworzyć w tym samym czasie. Można sobie wyobrazić fabrykę przyszłości, która na podstawie informacji z czujników o stanie maszyn automatycznie zoptymalizuje działanie pracujących w niej urządzeń, a także podejmie decyzję o przestawieniu produkcji, np. w razie zmiany zapotrzebowania na dany produkt na rynku. W przyszłości takie zadania jak predykcyjne serwisowanie, tj. regularne badanie stanu technicznego maszyn (predictive maintenance), będą realizowane na brzegu sieci, czyli blisko zdarzenia. Dlatego odpowiednio zaprojektowane protokoły sieciowe pomogą integrować różne systemy, aby tworzyły jeden ekosystem (rys. 4) (Tomczyk, 2020).

Należy zaznaczyć, że chiński rząd pod koniec 2019 r. w mieście Wuxi stworzył specjalny obszar o powierzchni $6 \mathrm{~km}$ kw., przeznaczony do testowania autonomicznych pojazdów komunikujących się ze sobą i otaczającą infrastrukturą za pośrednictwem pięciuset stacji bazowych 5G. W projekt zaangażowanych było trzynaście firm technologicznych, m.in. Ford, Audi, Huawei oraz China Mobile. Władze planują do końca 2022 r. powiększyć obszar do 1200 km kw., co zapewni pokrycie ponad połowy aglomeracji siecią. Takie rozwiązanie sprawi, że autonomiczne pojazdy będą zachowywać się w bardziej inteligentny sposób, np. kiedy dojdzie do niebezpiecznego zdarzenia na drodze, takiego jak wypadek czy pojawienie się innego pojazdu albo pieszego na kursie kolizyjnym. Pojazd otrzyma informację o zagrożeniu od innych autonomicznych samochodów i z czujników zamontowanych na drodze (Tomczyk, 2020).

W podobny sposób można zaprojektować fabrykę i poruszające się po niej roboty. Urządzenie otrzyma informację o zbliżającym się człowieku 
dzięki sensorom, monitoringowi firmy albo ze smartfonu znajdującego się w kieszeni pracownika, dzięki czemu robot zatrzyma się, zanim dojdzie do zderzenia. Ważne jest tu wskazanie, że podobne rozwiązanie przynosi korzyści skali na tej zasadzie, że im więcej jest połączonych urządzeń, tym większe będzie bezpieczeństwo i zarazem efektywność całego systemu.

Największe zainteresowanie sieć 5G budzi wśród dużych firm przemysłowych, w których działają lub są wdrażane systemy IIoT (Industrial Internet of Things). Ponadto prywatne sieci 5G mogą być instalowane w odległych i słabo rozwiniętych regionach nieposiadających infrastruktury 5G. Ich potencjalnymi użytkownikami mogą też być uniwersytety, szpitale, bazy wojskowe czy węzły transportowe (lotniska, porty, stacje kolejowe).

W fazie opracowywania są także standardy zapewniające niezawodną łączność dla aplikacji o znaczeniu krytycznym MCPTT (Mission-Critical Push To Talk). Tego typu systemy są przeznaczone np. dla służb odpowiedzialnych za bezpieczeństwo lub operatorów sieci kolejowych. Organizacja 3GPP (Green Public Procurement) już opracowała odpowiedni standard dla sieci LTE, a obecnie przygotowuje wersję dla 5G, która ma być rozszerzona o specyfikacje dotyczące niezawodnego przesyłania wideo i danych w czasie rzeczywistym (Mission Critical Video oraz Mission Critical Data).

Pierwsze testy prywatnych sieci 5G rozpoczęły się już w 2018 r. w Niemczech - rząd zaczął tam wspierać tego typu inicjatywy w ramach narodowego programu rozwoju Przemysłu 4.0. Nokia ogłosiła w 2020 r. wdrożenie prywatnych rozwiązań bezprzewodowych $5 \mathrm{G}$ m.in. w firmach Deutsche Bahn, Lufthansa Technik i Toyota Production Engineering. Prywatna sieć bezprzewodowa 5G jest też wdrażana w kopalni Sandvik Mining and Rock Technology w Tampere w Finlandii. Latem 2019 r. Mercedes-Benz i Ericsson ogłosiły uruchomienie pierwszej prywatnej sieci 5G w przemyśle motoryzacyjnym, która funkcjonuje w nowej fabryce tej firmy Factory 56.

Co się tyczy zarządzania licencjami na częstotliwości, to prekursorem w tej dziedzinie były Niemcy, które już w 2018 r. zaczęły wprowadzać regulacje umożliwiające wykorzystanie licencjonowanych pasm, ale wówczas tylko w celach testowych. Zajmuje się tym urząd BNA (Bundesnetzagentur), który ostatecznie wydzielił pasmo o szerokości $100 \mathrm{MHz}$ (w ramach częstotliwości 3,7-3,8 GHz) do lokalnych zastosowań w przemyśle i od listopada 2019 r. przyjmuje wnioski o udzielenie licencji na okres dziesięciu lat.

Natomiast Ofcom, brytyjska organizacja rządowa zajmująca się regulacjami związanymi z usługami telekomunikacyjnymi, wprowadziła w lipcu 
2019 r. system licencjonowania dostępu do częstotliwości 3,8-4,2 GHz, 1,8 GHz oraz 2,3 GHz wykupionej w 2020 r. przez operatorów komórkowych. W tym ostatnim przypadku Ofcom może udostępnić pasmo radiowe na obszarze, na którym nie jest ono wykorzystywane i nie ma planu jego wykorzystania w czasie najbliższych trzech lat.

Lokalne licencje będą udostępniane pod warunkiem zapewnienia, że system nie będzie zakłócał funkcjonowania operatorów sieci komórkowych, którzy wcześniej kupili ogólne licencje na częstotliwości. Warto jednak zwrócić uwagę na to, że nie dotyczy to pasma 3,8-4,2 GHz. Jak uważają specjaliści Ofcom, jest ono najbardziej predestynowane do zastosowań w prywatnych, przemysłowych sieciach 5G i nie będzie udostępniane do świadczenia usług publicznych (Pawłowicz, 2020). Należy zaznaczyć, że trzyletnia opłata licencyjna wynosi zaledwie 950 funtów brytyjskich i ma pokrywać jedynie koszty Ofcom związane z zarządzaniem licencjami. W 2020 r. urząd rozważał możliwości zarówno wydłużenia czasu licencji, jak i wprowadzenia licencji krótkotrwałych, np. dla organizatorów imprez masowych. Do marca 2020 r. do Ofcom wpłynęło dziewięć podań o lokalne udostępnienie licencji, z których jedno zostało zatwierdzone, cztery odrzucone, a cztery są analizowane (Pawłowicz, 2020).

W Stanach Zjednoczonych natomiast FCC (Federal Communications Commission) rozpoczęła w styczniu 2020 r. proces otwierania pasma 3,5 GHz do zastosowań komercyjnych. Pasmo określane jako CBRS (Citizens Broadband Radio Service) było wcześniej wykorzystywane do zastosowań militarnych i dysponowało nim Ministerstwo Obrony USA (Pawłowicz, 2020). Licencje na dostęp do częstotliwości są sprzedawane niezależnie dla każdego powiatu (hrabstwa) na trwającej wciąż aukcji. FCC będzie prowadzić licytację do czasu, gdy sprzedane zostaną licencje dla każdej lokalizacji (liczba hrabstw przekracza 3000). Zasady są komercyjne - nabywca ma prawo sam wykorzystać licencję, udostępnić ją innym firmom lub sprzedać po cenach rynkowych (Pawłowicz, 2020).

Powszechność i rozwój sieci $5 G$ rodzi też słuszne pytania o bezpieczeństwo i prywatność danych. W końcu coraz większa liczba urządzeń będzie mieć do nich bezpośredni dostęp, co zwiększa ryzyko cyberataków nie tylko na jednostki, ale i całe instytucje. Ta kwestia jest do rozstrzygnięcia, jednakże z poziomu infrastruktury całej sieci leży po stronie operatorów. Od nich zależy więc w dużej mierze cyfrowe bezpieczeństwo. Szef Urzędu Komunikacji Elektronicznej w Polsce zapewnia uspokajająco, że ten aspekt jest priorytetowy w projektowaniu gospodarki 5G oraz w tworzeniu ustawy dla operatorów telekomunikacyjnych. 


\section{Nowoczesne technologie informacyjno-komunikacyjne w czasie pandemii COVID-19}

W związku z pandemią COVID-19 wiele rządów wprowadziło radykalne ograniczenia aktywności społecznej i gospodarczej oraz bariery w podróżowaniu. Restrykcje dotknęły około połowy ludności świata i odbiły się negatywnie na światowej gospodarce (tab. 1). Najbardziej ucierpiał sektor usług, w tym takie branże, jak turystyka, transport i gastronomia. Spadła również konsumpcja (z wyjątkiem zakupów żywności). Ponadto wstrzymanie produkcji spowodowało zaburzenia w funkcjonowaniu globalnych łańcuchów wartości (global value chains - GVC, czyli dyslokacja procesu produkcji w wielu miejscach na świecie, zarówno w ramach jednej firmy, jak i wielu poddostawców) oraz handlu międzynarodowego, utrudniając utrzymanie produkcji nawet tam, gdzie jeszcze nie obowiązywały restrykcje. Tym samym kryzys ma charakter jednocześnie popytowy i podażowy, co utrudnia jego zażegnanie, a nawet zwiększa jego skalę.

Tabela 1. Nowe przypadki COVID-19 zgłaszane dziennie przez wybrane kraje świata, stan na 5-6 marca 2020 r.

\begin{tabular}{|l|c|c|c|}
\hline \multicolumn{1}{|c|}{ Kraj } & $\mathbf{6 . 0 3 . 2 0 2 0}$ & $\mathbf{5 . 0 3 . 2 0 2 0}$ & $\begin{array}{c}\text { Dzienny wzrost liczby } \\
\text { nowych przypadków }\end{array}$ \\
\hline Stany Zjednoczone & 74 & 34 & $118 \%$ \\
\hline Wielka Brytania & 30 & 34 & $-12 \%$ \\
\hline Kanada & 12 & 3 & $300 \%$ \\
\hline Francja & 138 & 73 & $89 \%$ \\
\hline Niemcy & 138 & 66 & $109 \%$ \\
\hline Włochy & 769 & 587 & $31 \%$ \\
\hline Japonia & 32 & 49 & $-35 \%$ \\
\hline
\end{tabular}

Źródło: za Baldwin i Weder di Mauro, 2020.

W czasie pandemii COVID-19 (rys. 6) zakłócenia związane z wirusami tylko w najważniejszych krajach Azji Wschodniej spowodowały „zarażenie łańcucha dostaw” praktycznie we wszystkich sektorach produkcyjnych w tych państwach (Baldwin i Weder di Mauro, 2020). Należy podkreślić, że ponad połowa światowej gospodarki w czasie COVID-19 została zainfekowana. Problem ten ilustruje tabela 2. 


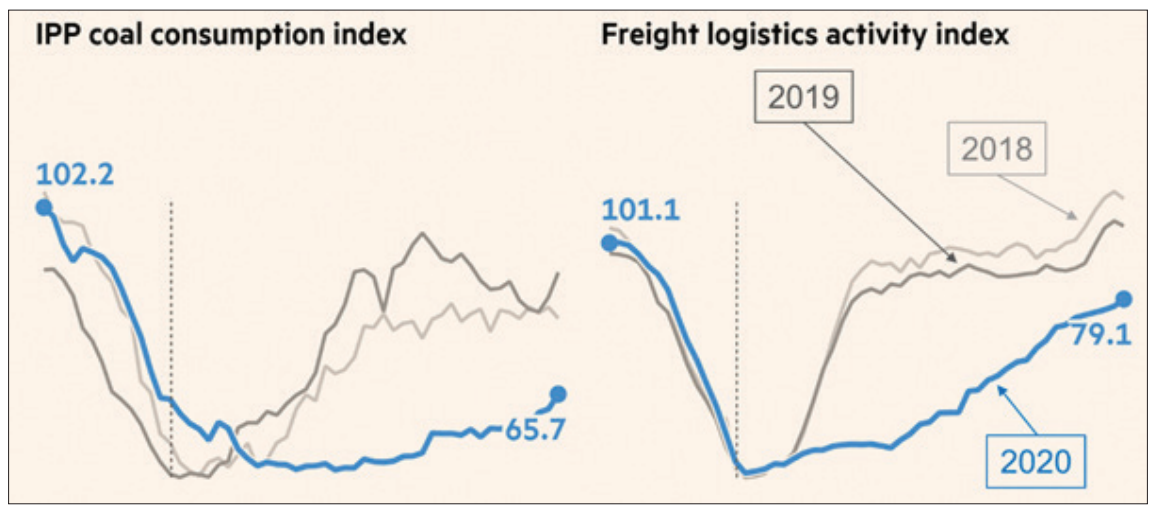

Rysunek 5. Gospodarka Chin ożywia się, ale nie poprawia.

Źródło: Financial Times COVID tracker.

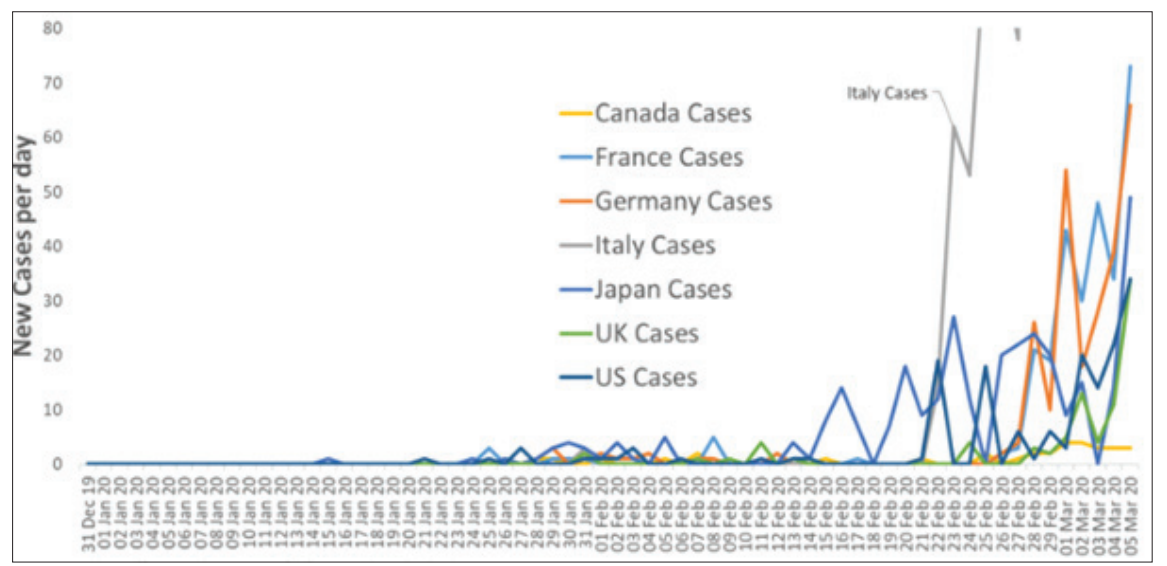

Rysunek 6. Wstrząs medyczny G7: krzywa epidemiologiczna COVID-19 (nowe przypadki dziennie).

Źródło: ECDC, https://www.ecdc.europa.eu/en/geographical-distribution2019-ncov-cases (dostęp: 2.04.2020).

Warto zaznaczyć, że Stany Zjednoczone, Chiny, Japonia, Niemcy, Wielka Brytania, Francja i Włochy stanowią:

- 60\% światowej podaży i popytu (PKB),

- 65\% światowej produkcji,

- 41\% światowego eksportu produkcji. 
Tabela 2. Duże gospodarki a COVID-19 (stan na dzień 5-6.03.2020)

\begin{tabular}{|l|c|c|c|c|c|c|}
\hline & PKB & $\begin{array}{c}\text { Artykuły } \\
\text { produk- } \\
\text { cyjne }\end{array}$ & Eksport & $\begin{array}{c}\text { Eksport } \\
\text { artykułów } \\
\text { produk- } \\
\text { cyjnych }\end{array}$ & $\begin{array}{c}\text { COVID-19 } \\
\text { zakażenia }\end{array}$ & $\begin{array}{c}\text { COVID-19 } \\
\text { zgony }\end{array}$ \\
\hline $\begin{array}{l}\text { Stany } \\
\text { Zjednoczone }\end{array}$ & $24 \%$ & $16 \%$ & $8 \%$ & $8 \%$ & 159 & 11 \\
\hline Chiny & $16 \%$ & $29 \%$ & $13 \%$ & $18 \%$ & 80410 & 2991 \\
\hline Japonia & $6 \%$ & $8 \%$ & $4 \%$ & $5 \%$ & 331 & 6 \\
\hline Niemcy & $5 \%$ & $6 \%$ & $8 \%$ & $10 \%$ & 262 & - \\
\hline $\begin{array}{l}\text { Wielka } \\
\text { Brytania }\end{array}$ & $3 \%$ & $2 \%$ & $2 \%$ & $3 \%$ & 85 & - \\
\hline Francja & $3 \%$ & $2 \%$ & $3 \%$ & $4 \%$ & 285 & 4 \\
\hline Indie & $3 \%$ & $3 \%$ & $2 \%$ & $2 \%$ & 28 & - \\
\hline Włochy & $2 \%$ & $2 \%$ & $3 \%$ & $3 \%$ & 3089 & 107 \\
\hline Brazylia & $2 \%$ & $1 \%$ & $1 \%$ & $1 \%$ & 4 & 4 \\
\hline Kanada & $2 \%$ & $0 \%$ & $2 \%$ & $2 \%$ & 34 & - \\
\hline
\end{tabular}

Źródło: Baldwin i Weder di Mauro, 2020; Economics in the Time of COVID-19, a VoxEU.org eBook, CEPR Press.

Można tu sparafrazować szczególnie trafny żart: kiedy te gospodarki kichną, reszta świata się przeziębia. Gospodarki te - zwłaszcza Chiny, Korea Południowa, Japonia, Niemcy i Stany Zjednoczone - są również częścią globalnych łańcuchów wartości, ich nieszczęścia spowodowały więc „zarażenie łańcuchów dostaw” praktycznie we wszystkich krajach (rys. 5 i 6). Pojawiły się też szoki podażowe. Najważniejszy wskaźnik aktywności zakładów produkcyjnych w Chinach, indeks menedżerów ds. zakupów w przemyśle Caixin/Markit (PMI), wykazał najniższy poziom w historii rozwoju tego państwa. Epidemia wywarła poważny wpływ na chińską gospodarkę przemysłową (rys. 5 i 6), co stwierdził nie bez przyczyny Zhengsheng Zhong, główny ekonomista Grupy CEBM. Według niego podaż i popyt osłabły, a łańcuchy dostaw uległy stagnacji. Podczas gdy chińska siła robocza stopniowo powracała do pracy, wskaźniki menedżerów ds. zakupów w całej Azji Wschodniej wykazywały gwałtowne spadki produkcji, zwłaszcza w Korei Południowej, Japonii, Wietnamie i na Tajwanie (Baldwin i Weder di Mauro, 2020).

Stan pandemii, obowiązywanie restrykcji i spadek aktywności konsumentów oznaczał pogorszenie kondycji finansowej wielu przedsiębiorstw, ich bankructwa i zwolnienia pracowników (tylko w Stanach Zjednoczonych zarejestrowano ponad $40 \mathrm{mln}$ nowych bezrobotnych (Domm, 2020). 
W efekcie wydarzenia te doprowadziły do recesji w USA i w strefie euro, a także w całej światowej gospodarce. Według Międzynarodowego Funduszu Walutowego (MFW) w 2020 r. zamiast przewidywanego wcześniej wzrostu o 3,3\%, globalny PKB spadł o 4,9\% (World Economic Outlook Update, 2020). Wyhamował również wzrost PKB na rynkach wschodzących, w tym w Chinach (wg MFW do 1\%, najmniejszy od lat siedemdziesiątych XX w.). Pandemia wpłynęła ponadto na rynki finansowe. W 2020 r. giełdy na całym świecie straciły łącznie ponad 20\% wartości, notując najgorsze wyniki od czasu globalnego kryzysu finansowego z lat 2007-2009. Wraz ze zmniejszeniem liczby zakażeń koronawirusem, stopniowym znoszeniem restrykcji i zwiększaniem aktywności gospodarczej, nastroje na giełdach poprawiały się, np. indeks S\&P 500 giełdy nowojorskiej wzrósł w 2020 r. o ponad 30\% (Egan, 2020). Jednakże wzrost liczby zachorowań, m.in. w USA, i osłabienie perspektywy szybkiego odbicia w gospodarce światowej przywróciły niepewność na rynkach finansowych.

Wahania były widoczne również na rynku walutowym, na którym zyskiwał głównie dolar. Najsilniej ucierpiały rynki wschodzące, z których początkowo w 2020 r. wycofano ok. 100 mld dolarów. Trend ten odwrócił się, gdy państwa rozwijające się przyciągnęły kapitał o wartości ok. 77 mld dolarów (World Economic Outlook Update, 2020). Należy zaznaczyć, że ewentualny odpływ kapitału w przypadku kolejnej fali zakażeń i pogorszenia sytuacji w gospodarce światowej może zagrozić stabilności ich gospodarek, np. możliwości obsługi długu. Dodatkowym uderzeniem w gospodarki państw rozwijających się, dla których ważne źródło przychodów budżetowych stanowi sprzedaż ropy naftowej, było załamanie się jej cen na światowych rynkach. Wobec osłabienia aktywności gospodarczej na świecie oraz wojny cenowej Arabii Saudyjskiej i Rosji (Bieliszczuk, 2020) cena ropy Brent spadła w 2020 r. poniżej 20 dolarów za baryłkę (najmniej od 2002 r.). Ponadto ograniczone możliwości magazynowania i przesyłu przy nadpodaży surowca doprowadziły na początku 2020 r. do pierwszych w historii ujemnych cen ropy West Texas Intermediate (WTI). Jednakże w kolejnych miesiącach 2020 r. cena ropy na światowych rynkach wyraźnie wzrosła, na co wpływ miało m.in. zwiększenie aktywności gospodarczej w wielu państwach znoszących restrykcje oraz zmniejszenie dostaw surowca uzgodnione przez OPEC i Rosję. W efekcie w połowie 2020 r. baryłka ropy WTI kosztowała ponad 35 dolarów (ponad 80\% więcej niż na początku maja 2020 r.), a ropy Brent 38 dolarów (wzrost w ciągu miesiąca o 96\%) - były to najwyższe miesięczne wzrosty w historii. Mimo to cena ropy naftowej 1 czerwca 2020 r. była o 33\% niższa niż na początku 2020 r. (Hirsch, 2020). Utrzymywanie się cen 
na tak niskim poziomie zmniejszyło opłacalność inwestycji wydobywczych, w tym m.in. w złoża łupkowe w Stanach Zjednoczonych (wydobycie z nich jest droższe niż ze złóż konwencjonalnych). Niskie ceny ropy naftowej wraz ze słabym popytem światowym wpływały na niską inflację.

Twórcy modeli makro w czasie koronawirusa byli zajęci opracowywaniem szacunków dotyczących rozmiarów szoku, jaki pojawił w światowej gospodarce. OECD szacowało scenariusz bazowy, w którym wybuch epidemii ograniczał się do Chin i kilku innych krajów. Scenariusz bazowy oznaczał spowolnienie światowego wzrostu o około 0,5\% w 2020 r. W scenariuszu spadkowym, w którym rozprzestrzenianie się było szeroko rozpowszechnione na półkuli północnej, światowy wzrost PKB w 2020 r. miał się zmniejszyć o 1,5\%. Większość wpływu przypisywano niższemu popytowi, ale w tym scenariuszu negatywny wpływ niepewności był również znaczący (Baldwin i Weder di Mauro, 2020). Warto też wskazać ewentualność, że kryzys mógł mieć kształt litery U, a nie litery V, jak to się działo w przypadku podobnych epidemii i innych niedawnych wstrząsów podażowych. Chodziło o to, że omawiane powiązania miały różny wpływ na różne narodowości. Mógł to być kształt litery V, czyli krótki i ostry, z pełnym powrotem do starej ścieżki wzrostu w niektórych sektorach i krajach, ale znacznie dłużej utrzymujący się w innych. Odbicie się w kształcie litery V było jednak bardzo mało prawdopodobne, zważywszy skalę spadku zatrudnienia, potężny spadek zagregowanego popytu, ograniczone możliwości wznawiania działalności oraz utrzymujący się szkodliwy wpływ COVID-19 na gospodarkę, którego konsekwencji nie można zniwelować w krótkiej perspektywie. Należało się natomiast spodziewać dłuższego i stopniowego odrabiania strat. Sugerowało to, że łącznie, przynajmniej w przypadku produkcji, sytuacja bardziej może przypominać kształt litery U (Baldwin i Weder di Mauro, 2020).

W przypadku sektora usług bardzo trudno będzie odzyskać wcześniejszą pozycję i dlatego sytuacja może wyglądać bardziej jak litera L. Konsumenci, którzy pominęli kilka posiłków w restauracji, kilka wyjść do kina oraz słoneczne wakacje, raczej nie podwoją liczby posiłków, wizyt w kinach i wakacji, aby nadrobić zaległości. Szok wywołany w obszarze turystyki, usług transportowych i związanych z gospodarstwem domowym raczej nie ustąpi. Największe konsekwencje z powodu epidemii wirusa poniosą również osoby wykonujące zawodowo prace domowe (sprzątaczki, pokojówki, kucharki) (Baldwin i Weder di Mauro, 2020).

Należy zaznaczyć, że pandemia COVID-19 najwyraźniej przyspieszyła bieg zmian, które w innych okolicznościach trwałyby co najmniej dekadę. Przykładem błyskawicznych zmian w niektórych branżach jest praca zdalna, 
zdalne nauczanie na wszystkich poziomach edukacji, zdalne uczestnictwo w wydarzeniach rozrywkowych i sportowych, większa popularność usług związanych z dostawami posiłków z restauracji, większa konsolidacja branżowa, przenoszenie łańcuchów dostaw z powrotem na rynki krajowe, bankructwa wielu małych przedsiębiorstw (w tym przede wszystkim sprzedawców detalicznych) oraz przenoszenie dużych węzłów komunikacji elektronicznej z miast do rejonów wymagających mniejszych kosztów.

Pandemia trwale zmieni obraz gospodarki światowej, skutkując częściowym odwrotem od globalizacji. Funkcjonowanie dotychczasowego modelu organizacji globalnych łańcuchów wartości i koncentrowanie produkcji w Azji, głównie w Chinach, pozwalało na minimalizację kosztów. Wojna celna USA z Chinami, a następnie trwający kryzys gospodarczy ujawniły jednak zagrożenia dla ich działań (Puślecki, 2020b). Po pierwsze, doszło do większej dywersyfikacji geograficznej inwestycji w zakłady wytwórcze (co działo się już wcześniej, m.in. ze względu na rosnące koszty pracy w ChRL). Po drugie, wzmocnił się proces przenoszenia produkcji bliżej rynków zbytu, aby zmniejszyć ryzyko prowadzenia działalności gospodarczej - w szerszym ujęciu może to dotknąć całą Azję. Japonia i Indie już wprowadzają mechanizmy wspierające przenoszenie produkcji poza Chiny (rozważają to też Stany Zjednoczone), aby zmniejszyć zależność od dostaw z tego państwa. Unia Europejska zapowiedziała zaś stworzenie Mechanizmu Inwestycji Strategicznych, który ma zachęcać rodzime firmy do lokowania w Europie produkcji w strategicznych sektorach, np. medycznym. Duża część inwestycji pozostanie jednak w Chinach ze względu na koszty przeniesienia zakładów i znaczenie rynku chińskiego. Po trzecie, firmy zapewne powrócą do gromadzenia zapasów, aby produkować mimo przerw w dostawach, podczas gdy wcześniejsze unikanie magazynowania pozwalało na oszczędności. Po czwarte, tym zjawiskom będzie towarzyszyć większa automatyzacja i robotyzacja produkcji, która niweluje różnice w kosztach pracy między państwami oraz pozwala ograniczyć ryzyko związane z globalnymi łańcuchami wartości.

Ponadto można się spodziewać zwiększenia skali protekcjonizmu (Puślecki, 2020a, b; 2021a, b) w celu ochrony gospodarek narodowych i spadku obrotów w handlu międzynarodowym oraz jego udziału w globalnym PKB. Według Światowej Organizacji Handlu tylko w 2020 r. globalna wymiana handlowa spadła między 13\% a 32 \% (Puślecki, 2021b). Na niektórych rynkach nastąpiły zmiany strukturalne, co wpłynie na rozwój firm, np. w sferze usług cyfrowych, których znaczenie wzrośnie wobec częstego ich wykorzystywania do zakupów w okresie restrykcji społecznych. 
Przyspieszenie procesu digitalizacji może wpłynąć na długofalowe zmiany organizacyjne w przedsiębiorstwach, w tym częstszą pracę zdalną części zatrudnionych i związane z tym ograniczanie kosztów wynajmu powierzchni biurowych.

Interesujące są oceny Warwicka McKibbina i Roshena Fernanda dotyczące wpływu wstrząsu wywołanego pandemią COVID-19 występującego tylko w Chinach i szoku globalnego o różnym stopniu nasilenia. W ich najpoważniejszym scenariuszu (z bardzo wysokimi wskaźnikami infekcji) wpływ na wzrost w 2020 r. był czterokrotnie większy niż w przypadku niekorzystnym dla indeksu Boone’ ${ }^{1}$. W tym scenariuszu Japonia była krajem z największą stratą prawie $10 \%$ PKB, następnie Niemcy i Stany Zjednoczone ze stratami po około 8\% (Baldwin i Weder di Mauro, 2020).

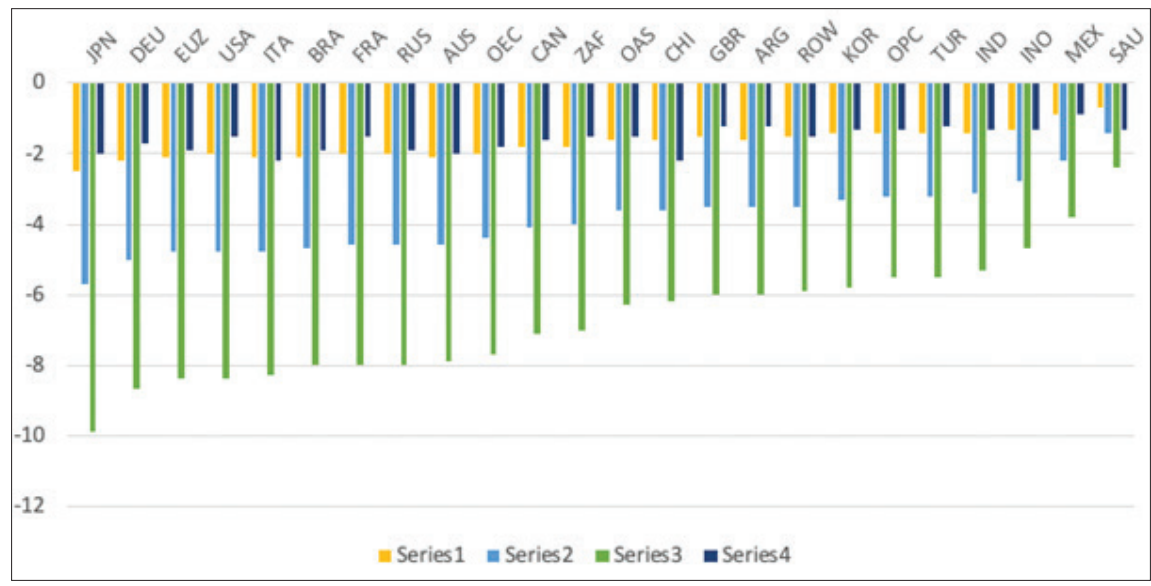

Rysunek 7. Strata PKB w 2020 r. Odchylenie od wartości wyjściowej (szacunki McKibbina i Fernanda, serie 1-4, globalne scenariusze pandemii). Źródło: Baldwin i Weder di Mauro, 2020.

Według Beatrice Weder di Mauro (Baldwin i Weder di Mauro, 2020): „Rozmiar i trwałość szkód gospodarczych będzie zależeć od tego, jak rządy poradzą sobie z tym nagłym, bliskim spotkaniem z naturą i strachem”. Może to stać się kryzysem gospodarczym o wymiarze globalnym i długotrwałym

${ }^{1}$ Szacowanie indeksu Boone’a opiera się na założeniu, że banki bardziej efektywne (o niższych kosztach krańcowych) mają większą siłę rynkową. Efekt ten jest tym silniejszy, im wyższy jest poziom konkurencji. Indeks Boone’a osiąga wartości mniejsze od zera. Im wyższy jest poziom konkurencji, tym większa jest jego wartość bezwzględna. 
odwróceniem się od globalizacji, ale może też być momentem, w którym decydenci zarządzą wspólną reakcję na kryzys. Może nawet uda im się odbudować zaufanie i stworzyć ducha współpracy, który pomoże ludzkości stawić czoła innym powszechnym zagrożeniom, takim jak zmiana klimatu.

Jednym z możliwych do rozważenia pomysłów jest zwiększenie Funduszu Solidarności Unii Europejskiej. Fundusz ten powstał w 2002 r. w celu wspierania jej państw członkowskich w przypadku dużych klęsk żywiołowych, takich jak powodzie, trzęsienia ziemi, erupcje wulkanów, pożary lasów, susze i inne klęski żywiołowe. Fundusz można uruchomić na wniosek danego kraju, pod warunkiem że klęska ma wymiar uzasadniający interwencję na szczeblu europejskim. W 2018 r. z Funduszu Solidarności UE wydano prawie 300 mln euro na pomoc w następstwie klęsk żywiołowych w Austrii, Włoszech i Rumunii.

Z pewnością zakłócenia spowodowane przez COVID-19 są równoznaczne z klęską żywiołową. W zwiększonej skali Fundusz Solidarności UE mógłby zapewnić wsparcie dotkniętym regionom i ich mieszkańcom, a oprócz natychmiastowej pomocy dałby ważny sygnał do zdecydowanego działania w kierunku pokonania wirusa.

Na podstawie dostępnych wyników badań należy stwierdzić, że w Polsce poszczególne firmy decydowały się przede wszystkim na ograniczenie inwestycji $(39,5 \%)$ oraz optymalizację procesów biznesowych $(38,5 \%)$. Ponad 27,5\% przedsiębiorców zredukowało wymiar czasu pracy, 23\% obniżyło wynagrodzenia, a 16\% zmieniło dotychczasowy model biznesowy. Na zmniejszenie zatrudnienia zdecydowało się 14\% badanych. 19\% firm, które wzięły udział w badaniu, nie wdrożyło i w najbliższym czasie nie planuje wdrożyć żadnych środków zaradczych.

W ciągu kolejnych miesięcy pandemii od lipca 2020 r. przedsiębiorcy dalej korzystali z rządowych rozwiązań antykryzysowych, ale na mniejszą skalę. Tylko 13\% przedsiębiorców brało pod uwagę dalszą redukcję zatrudnienia, a obniżkę wynagrodzeń rozważało 10\% badanych.

Oceniając pomoc z tarczy antykryzysowej, warto zaznaczyć, że około 40\% firm, które wzięły udział w badaniu, skorzystało ze wsparcia państwa w niewielkim lub średnim stopniu. 16,5\% respondentów wskazało, że tarcze w ogóle nie pomogły w przetrwaniu kryzysu. Tylko 10\% firm uznało, że rządowe rozwiązania antykryzysowe pomogły im w dużym lub bardzo dużym stopniu. Natomiast 33\% firm nie skorzystało z żadnych rozwiązań oferowanych firmom w ramach tarcz antykryzysowych. Rozważając kwestię powrotu do normalnego funkcjonowania, trzeba zauważyć, iż $40 \%$ przedsiębiorców szacowało, że ich firmy zaczną normalnie działać jeszcze 


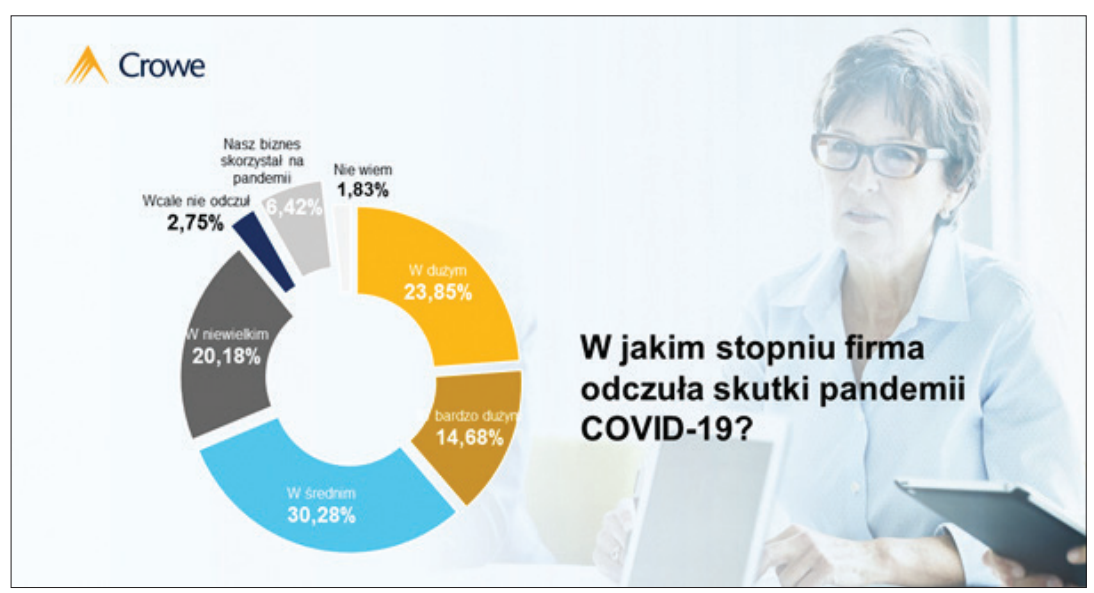

Rysunek 8. W jakim stopniu firma odczuła skutki pandemii?

Źródło: Crow, 2020.

w 2020 r., a 25\% respondentów jako datę zakończenia wychodzenia z kryzysu wskazało 2021 r. Tylko 22\% badanych firm stwierdziło, że mimo pandemii koronawirusa funkcjonowały jak dotychczas².

Patrząc w przyszłość, należy skupić się na ożywieniu handlu międzynarodowego i odrzuceniu pokus zamknięcia się we własnych granicach oraz zrywania światowych szlaków handlowych, tak istotnych dla dalszego rozwoju biznesu międzynarodowego. W 2020 r. nastąpił globalny spadek PKB na poziomie $4,3 \%$, co stanowi najgorszy wynik od czasów recesji w latach trzydziestych XX w. Podkreśla się, że jest to prawdziwy światowy kryzys, wskazując, iż 95\% państw świata zakończyło w 2020 r. z niższym dochodem na głowę mieszkańca niż w latach poprzednich. Przedwczesne wycofanie się z fiskalnych i finansowych programów pomocy wspierających gospodarkę może osłabić powrót do normalności. Pozytywnym objawem tej sytuacji jest zdolność do zachowania stabilności finansowej. Inaczej mówiąc, to, co zostało zrobione po kryzysie finansowym w 2008 r., pomaga w pokonaniu obecnej trudnej sytuacji. Świadczy o tym fakt, że system bankowy jest silny, stopy procentowe są niskie, a rządy państw w większości odpowiadają na zachodzące skomplikowane zjawiska rozwojowe.

2 Badanie „Biznes post-COVID-19” Crowe, Contract Administration i TGC Corporate Lawyers zostało przeprowadzone w dniach 4 czerwca - 6 lipca 2020 r. na grupie 109 respondentów. 
Według Międzynarodowego Funduszu Walutowego konsekwencje pandemii COVID-19 spowodowały, że 170 krajów świata w 2020 r. roku miało ujemny wzrost gospodarczy. Zauważono przy tym trzy najważniejsze czynniki, które zdołały się rozwinąć. Po pierwsze, zdolność państw do wykorzystania zasobów finansowych, tak by przez odpowiednie wprowadzenie ich na rynek zebrać wystarczające fundusze i wspierać odbudowę. Wskazywano, że w pierwszych tygodniach kryzysu rynki „zamarzły”, a w połowie $2020 \mathrm{r}$. widać już było, że gospodarki krajów rozwijających się wracały do aktywności i wypuściły na rynek ponad 80 mld dolarów. Po drugie, zauważono bardzo przejrzyste i udane działania w zakresie ochrony przedsiębiorstw przed bankructwem i drastycznym wzrostem bezrobocia.

Powyższe kwestie można zilustrować interesującą analizą sytuacji małych i średnich firm. Patrząc na sytuację siedemnastu krajów (w większości Europy Środkowej i Południowej), można ocenić, że gdyby nie podjęto żadnych działań, bankructw wśród tych firm byłoby trzykrotnie więcej. Miałoby to istotne negatywne skutki dla gospodarki. Jednocześnie dały się także zauważyć bardzo zdecydowane działania na rzecz państw o niskich przychodach w postaci programów zawieszania długu. Pojawiało się jednocześnie pytanie, co to oznaczałoby dla najbiedniejszych. W efekcie wymienionych działań nie musieliby podejmować dramatycznego wyboru między ratowaniem życia a wywiązywaniem się ze spoczywających na nich zobowiązaniach finansowych. Pojawiało się też następne pytanie, czy będzie to wydajne. Wskazywano na trzy najważniejsze kwestie: po pierwsze - system ochrony zdrowia. Jeżeli występowała potrzeba zachowania bezpieczeństwa w obliczu ryzyka drugiej fali pandemii, należało mieć przygotowane szpitale, a w nich lekarzy i pielęgniarki. Podkreślano, że powinno to być absolutnym priorytetem dla rządów poszczególnych państw; po drugie należało się upewnić, że wsparcie zapewniane biznesowi i rodzinom będzie trwało tak długo, jak długo będzie potrzebne. Wskazywano ponadto, że stopy procentowe były bardzo niskie, dlatego rządy i przedsiębiorstwa mogły być finansowane i refinansowane na korzystnych warunkach; po trzecie - trzeba było także pomyśleć o odbudowie. Z uznaniem można było zauważyć, że Unia Europejska zaakceptowała wart 750 mld euro pakiet odbudowy. Należało się jednak upewnić, że te środki finansowe zostaną skierowane na wspieranie transformacji, która będzie budować konkurencyjność UE w przyszłości.

W czasie pandemii COVID-19 niezbędne jest innowacyjne podejście firm do pojawiających się problemów rozwojowych. Podmioty wspierające przedsiębiorców duży potencjał widzą w start-upach, powszechnej cyfryzacji 
i działaniach zgodnych ze zrównoważonym rozwojem. W szczególności warto zwrócić uwagę na kraje, których narodowe systemy innowacji (NSI) są uznawane za wysoko rozwinięte, a funkcjonujące tam rozwiązania mogą stanowić inspirację dla działań w Polsce. Istotne są również inicjatywy wprowadzane przez rządy wielu krajów w celu powstrzymania konsekwencji pandemii. Według szacunków University of Cambridge koronawirus może kosztować globalną gospodarkę nawet 82 bln dolarów w ciągu pięciu lat. Dlatego pojawiają się różnorodne formy wsparcia, które mają pomóc społeczeństwom w przetrwaniu trwającej recesji.

Warto zaznaczyć, że poszczególne państwa doceniają potencjał start-upów. W świadomości społecznej są to podmioty postrzegane jako twórcy innowacji. Kraje na całym świecie doceniają ich wkład w rozwój gospodarek i dlatego chętnie oferują im programy ratowania płynności. Popularne są też konkursy na tworzenie innowacji, przede wszystkim mogących sprostać wyzwaniom spowodowanym pandemią. Wsparcie w wysokości 1 mld funtów oferuje start-upom walczącym z koronawirusem rząd Wielkiej Brytanii. Inwestycje będą mieć formę pożyczek zamiennych, co oznacza, że jeśli nie zostaną spłacone, zamieniają się w kapitał własny spółki. Specjalny program skierowany do start-upów powstał także w Luksemburgu. Koncentruje się on na opracowywaniu innowacyjnych produktów i usług opartych na technologiach mających na celu przezwyciężenie gospodarczych, zdrowotnych i społecznych skutków kryzysu związanego z pandemią. Wyłonione projekty otrzymają wsparcie w wysokości 150 tys. euro.

Wiele państw zdecydowało się na bardziej horyzontalne podejście do innowacji w czasie pandemii. Równie ważne co działania prozdrowotne, w latach 2020 i 2021 były kwestie związane ze zrównoważonym rozwojem. ONZ definiuje to pojęcie jako odpowiedź na aktualne potrzeby ludzi bez ograniczania przyszłym pokoleniom możliwości do zaspokojenia ich potrzeb. Zrównoważony rozwój wymaga podjęcia wspólnego wysiłku w budowę odpornej na skutki katastrof przyszłości dla wszystkich mieszkańców świata. Do jego osiągnięcia konieczna jest spójność zasadniczych elementów wzrostu gospodarczego, a mianowicie inkluzji społecznej i ochrony środowiska naturalnego.

Agencją, która odpowiada za zaspokojenie potrzeb wynikających z kryzysu w dziedzinie zdrowia, zmian klimatu, cyfryzacji, żywności, zrównoważonej energii, mobilności w mieście, produkcji i surowców, jest Europejski Instytut Innowacji i Technologii. Przedsiębiorcy mogą wziąć udział w kilku konkursach, które akcentują potrzebę działania w zgodzie z zasadami zrównoważonego rozwoju. Jednym z nich jest wsparcie projektów, które 
mogą stymulować tworzenie nowych miejsc pracy, dobrobyt i regenerację gospodarczą w obszarze europejskiej gospodarki ekologicznej. Wielość programów adresowanych do przedsiębiorców pokazuje, że nie można skupiać się tylko na dotychczasowej sytuacji, a każde działanie w czasie pandemii będzie mieć konsekwencje w przyszłości.

Walka z następstwami pandemii często sprowadza się do promowania rozwiązań w zakresie cyfryzacji przedsiębiorstw czy aplikacji cyfrowych wychodzących naprzeciw wyzwaniom społecznym. Celem niektórych państw jest taki rozwój małych i średnich przedsiębiorstw (MŚP), aby stały się liderami postępu technologii informacyjno-komunikacyjnych. Chiny proponują przedsiębiorcom program, który koncentruje się na trzech konkretnych obszarach: chmura, e-commerce i obecność w sieci. Państwo zapewnia firmom wsparcie w czasie kryzysu w celu cyfryzacji najważniejszych sektorów, jak branża spożywcza czy sektor farmaceutyczny. Program zachęca dostawców usług i rozwiązań technologicznych do podejmowania współpracy z MŚP i pomocy w przejściu do cyfrowego świata. Polskie firmy również mogą korzystać z podobnego wsparcia, na ten cel przeznaczone są m.in. środki z Programu Operacyjnego Inteligentny Rozwój. Wszystkie rozwiązania wspierające automatyzację procesów w firmie, pracę zdalną, wykorzystywanie rozwiązań chmurowych czy sztucznej inteligencji pomagają firmom zyskać przewagę konkurencyjną.

Równie ważne jest oferowanie profesjonalnego doradztwa w kwestiach digitalizacji modeli biznesowych. Pomoc skupia się głównie na udzielaniu wsparcia w tworzeniu kanałów cyfrowych, wideo chatów, stron internetowych czy sklepów internetowych. Celem takich działań jest pomoc firmom w dotarciu do zróżnicowanych grup klientów. Popularne są też interaktywne sesje online i seminaria internetowe dotyczące tematyki wsparcia biznesów przez innowacje techniczne i technologiczne.

Należy zauważyć, że wszystkie omówione działania aktywnie promuje Japonia, która w czasie pandemii może być wzorem dla innych gospodarek. Rząd japoński wyda ponad 830 mln euro w ciągu najbliższych pięciu lat na program, który obejmuje rozwój diagnostyki wczesnego wykrywania i zapobiegania chorobom, zrównoważone metody recyklingu odpadów, zrównoważoną produkcję żywności oraz rozwój komputerów kwantowych. W planach są ponadto intensywne prace nad udoskonalaniem sztucznej inteligencji, a konkretnie stworzenie robota, który odtworzy człowieka i jego zdolności. Nowy, zorientowany na misję wysiłek Japonii odzwierciedla potrzebę sprostania największym wyzwaniom tego kraju, takim jak starzenie się populacji szybciej niż gdziekolwiek w rozwiniętym świecie. 


\section{Podsumowanie}

W nadchodzącym czasie sukces naukowy czy w zakresie obsługi klienta będzie zależeć od posiadania strategii opartej na analizie danych. Automatyzacja będzie odgrywać zasadniczą rolę w inicjatywach z zakresu badań naukowych oraz obsługi pracownika. Istotne będą postępy i wdrożenia automatyzacji procesów opartej na robotach, a także uczenia maszynowego, sztucznej inteligencji, internetu rzeczy, budowie sieci piątej generacji (5G). Nowoczesna technologia staje się jednocześnie narzędziem inwigilacji społeczeństwa.

W następstwie globalnego kryzysu wywołanego pandemią COVID-19 niepewność w gospodarce światowej skłoniła wiele firm do ponownej oceny swoich modeli biznesowych. Zamiast polegać na globalnych łańcuchach dostaw, coraz więcej firm inwestowało w roboty, co spowodowało renesans produkcji w krajach uprzemysłowionych. Zmiany w światowej gospodarce spowodowane COVID-19 sprawiały, że wyjście z recesji w kształcie litery V będzie mało prawdopodobne. Można natomiast przewidywać, że zamiast tego COVID-19 przyspieszy proces zapoczątkowany po globalnym kryzysie, zachęcając firmy do ponownego przeniesienia działalności do państw bogatych.

Czas pandemii uwydatnił atuty rynków wschodzących w takich obszarach, jak system opieki społecznej, jakość sprawowania rządów czy ochrona zdrowia. Pojawiły się także efekty reform budżetowych i reform dotyczących spółek, jakie zrealizowano w ciągu ostatnich dwóch dekad. Solidne bilanse rynków wschodzących okazały się źródłem ich odporności, co prawdopodobnie nie ulegnie zmianie w przyszłości.

Warto ponadto zauważyć, że utrzymywanie dużych zasobów środków finansowych netto, które kiedyś uznawane było za mało efektywne podejście, okazało się polityką rozważną. Takie państwa, jak Brazylia, Indie, Chiny i Korea Południowa skorzystały na efektach reform instytucjonalnych zrealizowanych w latach poprzednich, dzięki którym u progu kryzysu wynikającego z COVID-19 miały mocniejsze fundamenty i większą elastyczność polityki budżetowej na tle danych historycznych państw zachodnich, co jest również korzystne dla szybszego odbicia się z trwającego zastoju gospodarczego.

Nie bagatelizuje się też problemu zmieniającego się klimatu. Kilka lat temu rząd Japonii podjął decyzję o oparciu gospodarki kraju na odnawialnych 
źródłach energii oraz wodorze. Celem nowych koncepcji jest stworzenie społeczeństwa wodorowego, co w konsekwencji doprowadzi do zmniejszenia emisyjności gospodarki i uniezależnienia jej od paliw kopalnych. Należy także podkreślić, że Japonia stanie się wtedy niezależna energetycznie.

Najważniejsze organizacje dysponują uporządkowanymi, wyważonymi programami innowacji, które dostosowują innowacje do strategii biznesowych i długoterminowego krajobrazu technologicznego. Przyjmują one programowe podejście do wyczuwania, badania i weryfikowania przyszłych sił makrotechnologicznych, takich jak doświadczenie otaczające, inteligencja wykładnicza czy technologia kwantowa, oraz do eksperymentowania z tymi siłami i przyczyniania się do ich zaistnienia, aż do momentu, gdy technologie, rynek i zastosowania biznesowe będą gotowe do działania. Pozostałe organizacje powinny rozważyć pójście ich śladem, wykorzystanie nabytej wiedzy do zdefiniowania na nowo i przekształcenia swoich agencji i organizacji, zanim dosięgnie je destabilizacja. W świecie, w którym niewiadome wydają się nie mieć końca, wciąż można skupić się na grupie istotnych, znanych technologii, które razem mogą wytyczyć drogę wiodącą ku kolejnemu horyzontowi rozwoju naukowego i biznesowego.

Wszelkie wdrażane rozwiązania muszą być wsparte systemami cyberbezpieczeństwa, ponieważ w przyszłości wzrośnie jego znaczenie dla lojalności klientów i dobrostanu pracowników. Należy podkreślić, że 83,2\% organizacji całkowicie przebudowało własne zabezpieczenia, aby uwzględnić nowe sposoby wykonywania pracy będące skutkiem pandemii. Szkolenia z zakresu nowych aplikacji i nowych sposobów wykonywania pracy zajmują wszakże odległą pozycję na liście priorytetów, co wiąże się z wysokim poziomem ryzyka. Kwestie te wymagają poprawy i szybkich zmian.

Realizacja programów edukacyjnych w dziedzinie bezpieczeństwa, informowanie pracowników o aktualizacjach zasad bezpieczeństwa i ich przełożeniu na wykonywanie codziennych czynności bez względu na lokalizację, a także komunikowanie oczekiwań, mają zasadnicze znaczenie dla kształtowania pożądanych zachowań oraz, co istotne, dla przekonania o celowości działań w zakresie cyberbezpieczeństwa.

Rozwiązania oparte na sztucznej inteligencji, określane mianem „informatyki afektywnej” bądź „emocjonalnej AI”, definiują na nowo sposób, w jaki doświadczamy technologii. W nadchodzącym czasie coraz więcej instytucji, w tym naukowych, będzie odpowiadać na rosnące, lecz w dużym stopniu niezaspokojone zapotrzebowanie, na nowoczesną technologię, która będzie lepiej rozumieć ludzi i szerzej z nimi współpracować. Nowoczesnymi technologiami, które szczególnie zyskają na znaczeniu w ciągu 
najbliższych lat za sprawą rozwoju sieci nowej generacji technologicznej 5G, są rzeczywistości wirtualna i rozszerzona. Urządzenia internetu rzeczy staną się doskonalsze dzięki algorytmom sztucznej inteligencji. Transferowane z wielu źródeł, ogromne ilości danych o klientach, uzyskiwane, rejestrowane i zarządzane przez większość organizacji, będą wzrastać w sposób wykładniczy.

\section{Literatura}

Baldwin, R., Weder di Mauro, B. (red.) (2020). Economics in the Time of COVID-19, A VoxEU.org Book, CEPR Press.

Baldwin, R., Forslid, R. (2020). Globotics and Development: When manufacturing is jobless and services are tradable. CEPR Discussion Paper, 14293.

Baldwin, R., Evenett, S. (2020). COVID-19 And Trade Policy: Why Turning Inward Won't Work. London: CEPR Press.

Bieliszczuk, B. (2020). Załamanie cen ropy naftowej - konsekwencje gospodarcze i polityczne. Biuletyn PISM, 71(2003).

Bussel, J. (2011). Explaining cross-national variation in government adoption of new technologies. International Studies Quarterly, 55(1), 267-280.

Camacho, J.A., Rodríguez, M. (2004). The Role of Services in the European National Innovation Systems: Are They 'Real diffusers'?, Department of Applied Economics. University of Granada, DRUID Summer Conference 2004 on Industrial Dynamics, Innovation and Development Elsinore, Denmark, June 14-16, 2004.

Cellary, W. (2019). Przemysł 4.0 i Gospodarka 4.0. Biuletyn Polskiego Towarzystwa Ekonomicznego, 3(86), 48-52.

China Statistical Yearbook 2019 (2019). http://www.stats.gov.cn/tjsj/ndsj/2019/indexeh. htm (dostęp: 9.01.2021).

Chińska gospodarka zapomniała o pandemii. PKB kraju wzrosło o 4,9 proc. (2020), 19.10.2020. https://forsal.pl/swiat/chiny/artykuly/7981796,pkb-chin-iii-kwartal2020-wzrost-gospodarczy-chiny.html (dostęp: 8.01.2021).

Cooke, P., Leydesdorff, L. (2006). Regional development in the knowledge-based economy: The construction of advantage. Journal of Technology Transfer, 31(1), 5-15.

Chen, T.-Y., Tsai, M.-Ch., Chen, Y.-M. (2016). A user's personality prediction approach by mining network interaction behaviors on Facebook. Online Information Review, 40(7), 913-937.

Czym jest technologia 5G i czy jest bezpieczna? Fakty i mity dotyczqce nowej generacji sieci (2020). https://geex.x-kom.pl/wiadomosci/czym-jest-technologia-5g-i-czyjest-bezpieczna-fakty-i-mity-dotyczace-nowej-generacji-sieci/ (dostęp: 19.01.2021).

Domm, P. (2020). Jobs data shows millions went back to work but unemployment rate for May is still expected at 20\%, CNBC, 28.05.2020, www.cnbc.com (dostęp: 20.08.2020).

Eagle, N., Pentland, A. (2014). Combined short range radio network and cellular telephone network for interpersonal communications, MIT ID: 10705T, US US7877082B2, 
filed May 6, 2004, and issued September 19, 2014, https://patents.google.com/patent/ US20150006207A1/en (dostęp: 10.07.2015).

Egan, M. (2020). Is the bear market over? Wall Street isn't so sure, CNN, 19.05.2020, www.edition.cnn.com (dostęp: 15.11.2020).

Frączyk, J. (2020). Potężne załamanie w amerykańskiej gospodarce. Powtórka z Wielkiego Kryzysu. https://businessinsider.com.pl/finanse/makroekonomia/pkb-usa-w-ii-kw2020-skurczyl-sie-o-jedna-trzecia-zalamanie-na-miare-wielkiego (dostęp: 30.12.2020).

Hirsch, R. (2020). Pięć najciekawszych tematów gospodarczych teraz, Business Insider, 1.06.2020, www.businessinsider.com.pl (dostęp: 15.11.2020).

Internet Rzeczy i sztuczna inteligencja zmieniq firmy na całym świecie. Znamy nowe dane (2020). Ostatnia aktualizacja: 22.12.2020. https://www.polskieradio24.pl/42/273/ Artykul/2645989,Internet-Rzeczy-i-sztuczna-inteligencja-zmienia-firmy-na-calymswiecie-Znamy-nowe-dane (dostęp: 12.01.2021).

Guangyuan, L. (2020). Pogłębianie reform i rozwoju w Chinach - okazja dla całego świata, 11.06.2020. http://www.chinaembassy.org.pl/pol/dsxx/dshd/t1787958.htm (dostęp: 9.01.2021).

Kalwasiński, M. (2020). Chiny: kryzys i po kryzysie? Bankier.pl, 16.07.2020. https:// www.bankier.pl/wiadomosc/Chiny-kryzys-i-po-kryzysie-7926337.html (dostęp: 20.12.2020).

Kilic, K., Marin, D. (2020). A New Era of World Trade: Global Value Chains and Robots. München: TUM School of Management, Technische Universität München, Mimeo.

Klein, N. (2007). The Shock Doctrine: The Rise of Disaster Capitalism. New York: Picador.

Olszewski, D. (2020). Kompendium 5G - wszystko, co musisz wiedzieć o nowej generacji sieci, 17.08.2020. https://www.pcworld.pl/news/Kompendium-5G-wszystko-co-musiszwiedziec-o-nowej-generacji-sieci,422226.html (dostęp: 19.01.2021).

Kugiel, P. (2020). Zagrożenie pandemią COVID-19 w państwach rozwijających się. Biuletyn PISM, 70.

Kupchan, Ch.A. (2014). Unpacking hegemony: The social foundations of hierarchical order. W: G.J. Ikenberry (red.), Power, Order, and Change in World Politics. Cambridge: Cambridge University Press.

Lee, A. (2020). China debt: How big is it, who owns it and what is next? South China Morning Post, 19 maja. www.scmp.com (dostęp: 20.12.2020).

Mazurek, M. (2020). Chiny otrzq̨snęły się z koronawirusa. PKB w górę o 4,9 proc. W G20 mogq być jedyne ze wzrostem w tym roku, 19.10.2020. https://next.gazeta.pl/ next/7,151003,26410771,chiny-ostrzasnely-sie-z-koronawirusa-pkb-w-gore-o-4-9proc.html (dostęp: 8.01.2021).

McKibbin, W., Fernando, R. (2020). 15 mln ludzi umrze, gospodarka straci biliony. Oszacowano szkody, które może przynieść koronawirus, 6.03.2020. https://www.polsatnews. pl/wiadomosc/2020-03-06/15-mln-umrze-a-gospodarka-straci-23-biliony-dolarownajnowsze-szacunki-dot-koronawirusa/ (dostęp 23.09.2020).

Meijers, H., Dachs, B., Welfens P. (red.) (2008). Internationalisation of European ICT Activities, Dynamics of Information and Communications Technology. Berlin-Heidelberg: Springer-Verlag.

Pawłowicz, W. (2020). 5G jako sieć LAN nowej generacji, 21.08.2020. https://www.computerworld.pl/news/NetApp-tnie-ceny-macierzy,424015.html (dostęp: 19.01.2021). 
Pentland, A. (2011). Society's Nervous System: Building Effective Government, Energy, and Public Health Systems, MIT Open Access Articles, October. http://dspace.mit. edu/handle/1721.1/66256 (dostęp: 19.01.2021).

Pentland, A. (2013). The data-driven society. Scientific American, 309, October, 78-83. https://doi.org/doi:10.1038/scientificamerican1013-78.

Piotrowski, M. (2020). Konsekwencje pandemii COVID-19 dla sił zbrojnych USA. https:// pism.pl/publikacje/Konsekwencje_pandemii_COVID19_dla_sil_zbrojnych_USA (dostęp: 31.12.2020).

Płóciennik, S. (2020). Koniec „czarnego zera” - druga fala działań antykryzysowych w Niemczech. Biuletyn PISM, 57(1989).

Poncet, S. (2006). The Long Term Growth Prospects of the World Economy: Horizon 2050. Paris: Centre d'Etudes Prospectives et d'Informations Internationales.

Poniewierski, A. (2020). AI od pierwszych dni szkoły podstawowej, 15.12.2020. https:// cyfrowa.rp.pl/opinie/55828-aleksander-poniewierski-ai-od-pierwszych-dni-szkolypodstawowej (dostęp: 12.01.2021).

Przychodniak, M. (2020). Przygotowania Chin do drugiej fali pandemii COVID-19. Biuletyn PISM, 248(2180).

Przychodniak, M., Wnukowski, D. (2020). Wpływ pandemii COVID-19 na gospodarkę Chin. Biuletyn PISM, 106(2038).

Puślecki, Z.W. (2013). International Business Theory and International Economy. Saarbrücken: LAP LAMBERT Academic Publishing is a trademark of OmniScriptum GmbH\&Co. KG.

Puślecki, Z.W. (2018a). European Union-China: Trade Relationships. Warszawa: CeDeWu.

Puślecki, Z.W. (2018b). The impact of increasing global supply chains on the foreign trade policy. Journal of International Research in Economics and Finance, 1(1), Singapore.

Puślecki, Z.W. (2019a). New Tendencies in Contemporary Foreign Trade Policy. Journal of Economics, Management and Trade, 25(3). https://doi.org/doi:10.9734/jemt/2019/ v25i330195.

Puślecki, Z.W. (2019b). Trends Reshaping International Business Theory and Policy. Warszawa: Publishing House ELIPSA.

Puślecki, Z.W. (2020a). The Need to Establish a New Format for Trade Political Relations Between European Union and China. Warszawa: CeDeWu.

Puślecki, Z.W. (2020b). World Economy Against New Challenges in the Time of COVID-19. Warszawa: Publishing House ELIPSA.

Puślecki, Z.W. (2021a). Handel zagraniczny. Transformacja biznesu międzynarodowego. Warszawa: Wydawnictwo Naukowe PWN.

Puślecki, Z.W. (2021b). Światowa Organizacja Handlu i Unia Europejska wobec wyzwań we współczesnym biznesie międzynarodowym. Warszawa: Wydawnictwo C.H. Beck.

Rząd przyjął strategię rozwoju sztucznej inteligencji. Znamy jej szczegóły (2020). Ostatnia aktualizacja: 14.09.2020. https://www.polskieradio24.pl/42/273/Artykul/2558247,Ministercyfryzacji-wirtualne-prawo-jazdy-wejdzie-w-zycie-trzy-miesiace-po-publikacji-ustaw (dostęp: 12.01.2021).

Stefański, M. (2020). Powszechne twierdzenia na temat gospodarek rozwiniętych to mity. https://www.obserwatorfinansowy.pl/bez-kategorii/rotator/powszechne-twierdzeniana-temat-gospodarek-rozwinietych-to-mity/ (dostęp: 18.12.2020). 
Strategia na rzecz doskonałości naukowej, nowoczesnego szkolnictwa wyższego, partnerstwa z biznesem i społecznej odpowiedzialności nauki (2016). https://pjg.org.pl/wp-content/ uploads/2016/09/Strategia-Gowina.pdf (dostęp: 10.10.2020).

Tomczyk, J. (2020). 5G - klucz do przemysłowej przyszłości, 20.11.2020. https://przemyslprzyszlosci.gov.pl/5g-klucz-do-przemyslowej-przyszlosci (dostęp: 12.01.2021).

Trivedi, A. (2020). Kolejny plan pięcioletni Chin może zachwiać przemysłem wysokich technologii na Zachodzie (OPINIA), 19.10.2020. https://forsal.pl/swiat/ chiny/artykuly/7848454,kolejny-plan-piecioletni-chin-moze-zachwiac-przemyslemwysokich-technologii-na-zachodzie-opinia.html (dostęp: 8.01.2021).

World Economic Outlook Update (June 2020): A Crisis Like No Other (2020). An Uncertain Recovery, MFW, www.imf.org (dostęp: 8.01.2021). 